\title{
Mouse Models of NMNAT1-Leber Congenital Amaurosis (LCA9) Recapitulate Key Features of the Human Disease
}

Scott H. Greenwald, ${ }^{*}$ Jeremy R. Charette, ${ }^{\dagger}$ Magdalena Staniszewska, ${ }^{*}$ Lan Ying Shi, ${ }^{\dagger}$ Steve D.M. Brown,${ }^{\ddagger}$ Lisa Stone, ${ }^{\dagger}$ Qin Liu, ${ }^{*}$ Wanda L. Hicks, ${ }^{\dagger}$ Gayle B. Collin, ${ }^{\dagger}$ Michael R. Bowl, ${ }^{\ddagger}$ Mark P. Krebs, ${ }^{\dagger}$ Patsy M. Nishina, ${ }^{\dagger}$ and Eric A. Pierce ${ }^{\star}$

From the Ocular Genomics Institute, * Department of Ophthalmology, Massachusetts Eye \& Ear Infirmary, Harvard Medical School, Boston, Massachusetts; The Jackson Laboratory, ${ }^{\dagger}$ Bar Harbor, Maine; and the Mammalian Genetics Unit, ${ }^{\ddagger}$ Medical Research Council (MRC), Harwell Campus, Oxfordshire, United Kingdom

\author{
Accepted for publication \\ March 16, 2016. \\ Address correspondence to \\ Eric A. Pierce, M.D., Ph.D., \\ Ocular Genomics Institute, \\ Department of Ophthalmology, \\ Massachusetts Eye \& Ear In- \\ firmary, Harvard Medical \\ School, 243 Charles St., \\ Boston, MA 02114. \\ E-mail: eric_pierce@meei. \\ harvard.edu.
}

\begin{abstract}
The nicotinamide nucleotide adenylyltransferase 1 (NMNAT1) enzyme is essential for regenerating the nuclear pool of $\mathrm{NAD}^{+}$in all nucleated cells in the body, and mounting evidence also suggests that it has a separate role in neuroprotection. Recently, mutations in the NMNAT1 gene were associated with Leber congenital amaurosis, a severe retinal degenerative disease that causes blindness during infancy. Availability of a reliable mammalian model of NMNAT1-Leber congenital amaurosis would assist in determining the mechanisms through which disruptions in NMNAT1 lead to retinal cell degeneration and would provide a resource for testing treatment options. To this end, we identified two separate $\mathrm{N}$-ethyl- $\mathrm{N}$-nitrosourea-generated mouse lines that harbor either a p.V9M or a p.D243G mutation. Both mouse models recapitulate key aspects of the human disease and confirm the pathogenicity of mutant NMNAT1. Homozygous Nmnat1 mutant mice develop a rapidly progressing chorioretinal disease that begins with photoreceptor degeneration and includes attenuation of the retinal vasculature, optic atrophy, and retinal pigment epithelium loss. Retinal function deteriorates in both mouse lines, and, in the more rapidly progressing homozygous Nmnat $^{\text {V9M }}$ mutant mice, the electroretinogram becomes undetectable and the pupillary light response weakens. These mouse models offer an opportunity for investigating the cellular mechanisms underlying disease pathogenesis, evaluating potential therapies for NMNAT1-Leber congenital amaurosis, and conducting in situ studies on NMNAT1 function and NAD metabolism. (Am J Pathol 2016, 186: 1925-1938; http://dx.doi.org/10.1016/j.ajpath.2016.03.013)
\end{abstract}

Leber congenital amaurosis (LCA), a genetically heterogeneous retinal degenerative disease associated with mutations in at least 18 genes, represents the most common cause ( $10 \%$ to $18 \%$ ) of incurable blindness in children ${ }^{1,2}$ and accounts for $\geq 5 \%$ of all inherited retinal degenerations. ${ }^{3}$ Across all forms of LCA, vision is impaired at birth or begins deteriorating during early infancy because of retinal degeneration. ${ }^{4}$ Patients often develop nystagmus, and, as the disease advances, amaurotic pupils may be observed ${ }^{2}$ because of the absence of functioning photoreceptors and intrinsically photosensitive ganglion cells. ${ }^{5,6}$ Both rod and cone photoreceptors degenerate rapidly, and many patients have no detectable electroretinogram (ERG) response after the first year of life. ${ }^{4}$ Although LCA can be a feature of syndromic diseases, each form of this retinal degeneration is caused by mutations in a single gene, and most cases are recessively inherited ${ }^{2}$ (RetNet, https://sph.uth.edu/retnet/ disease.htm, accessed March 7, 2016).

\footnotetext{
Supported by NIH/National Eye Institute grants EY012910 (E.A.P.), 5 T32 EY-007145-16 (S.H.G.), EY016501 (P.M.N.), P30 EY003790 (Schepens Ophthalmology Core), P30 EY014104 (Massachusetts Eye and Ear Infirmary Ophthalmology Core); the Foundation for Retinal Research/Gavin R. Stevens Foundation (E.A.P.); Fight for Sight (PD15001; S.H.G.); and NIH/ National Cancer Institute grant CA34196 (The Jackson Laboratory).

Disclosures: None declared.

Current address of M.S., Institute of Immunology and Experimental Therapy, Polish Academy of Sciences, Wroclaw, Poland.
} 
Genes that harbor mutations responsible for LCA have critical roles in different cell types throughout the retina. ${ }^{2,7}$ A substantial portion (approximately 5\%) ${ }^{8}$ of LCA cases are caused by mutations in the NMNATl gene, ${ }^{1,8-15}$ which encodes the nicotinamide nucleotide adenylyltransferase 1 (NMNAT1) enzyme that is essential for regenerating the nuclear pool of $\mathrm{NAD}^{+}$. Nuclear $\mathrm{NAD}^{+}$, synthesized from ATP and either nicotinic acid mononucleotide or nicotinamide mononucleotide, is important for processes related to DNA repair, gene expression, cell senescence, and cell signaling. ${ }^{16-18}$ In the Golgi complex and mitochondria, two other NMNAT isoforms that similarly serve to regenerate $\mathrm{NAD}^{+}$are encoded by NMNAT2 and NMNAT3, respectively. ${ }^{17,19}$ However, neither NMNAT2 nor NMNAT3 compensates for the loss of NMNAT1 function, considering that homozygous knockout of Nmnatl in mice results in embryonic lethality. ${ }^{20}$ Moreover, multiple lines of evidence indicate that NMNAT1 may have neuroprotective chaperone and housekeeping functions that are separate from its role in the $\mathrm{NAD}^{+}$synthesis pathway. ${ }^{21-26}$ As an example, the Wallerian degeneration slow $\left(\mathrm{Wld}^{\mathrm{S}}\right)$ fusion protein that delays axon degeneration after nerve injury in $W l d^{S}$ mice includes full-length Nmnat1 fused to a portion of the Ube $4 b$ multi-ubiquitination factor. ${ }^{22,24}$ Given that NMNAT1 is expressed ubiquitously, ${ }^{9,19}$ it is unclear why abnormal NMNAT1 function causes a retina-specific disease.

The precise mechanism(s) underlying retinal cell degeneration in NMNATI-LCA also has not been defined, and no treatment is available for patients. Thus far, in the absence of an animal model, mutant NMNAT1 has been studied in human embryonic kidney cells (HEK293T), human cervical cancer cells (HeLa), mouse dorsal root ganglia, NMNAT1LCA patient fibroblasts, and NMNATI-LCA patient red blood cells (nonnucleated), , 10,27,28 with inconsistent results. Further, in vitro systems do not allow for the assessment of whether a treatment preserves vision and cannot address practical challenges associated with delivering therapeutic agents to the NMNATI-LCA retina. For instance, determining which specific cell type(s) should be the therapeutic target may be critical for a successful intervention, given that the effects of NMNAT1 overexpression in otherwise healthy retinal cells are unknown.

Here, we report the discovery and characterization of two mutant Nmnatl mouse lines derived from chemical mutagenesis programs. ${ }^{29,30}$ Wild-type mice were injected with a potent mutagen, $N$-ethyl- $N$-nitrosourea (ENU), which introduces point mutations in DNA that are transmissible through the germline. Mutations in Nmnatl were identified, and multiple outcrosses with wild-type mice served to eliminate most ENU-induced mutations at other chromosomal locations. ${ }^{31}$ One line harbors the p.V9M mutation, which was observed to cause LCA in patients from unrelated families and has been investigated in two separate studies. ${ }^{8,27}$ The other line harbors a novel mutation, p.D243G, which has yet to be reported in the human population (ExAC Browser, http://exac.broadinstitute.org, accessed March 7, 2016). The retinal degenerative phenotype observed in both lines recapitulates key aspects of NMNAT1-LCA. These mouse models show promise for elucidating pathologic mechanisms associated with NMNAT1-LCA, developing therapies for patients with this disease, and understanding the roles of NMNAT1 in neuroprotection and $\mathrm{NAD}^{+}$metabolism.

\section{Materials and Methods}

\section{Identification of Nmnat1 ${ }^{\text {VgM }}$ Mice}

Mice expressing the p.V9M variant of NMNAT1 were derived from a gene-driven screen of the Harwell ENU DNA archive to identify Nmnatl missense alleles. The archive consists of pooled DNA samples from $>10,000$ ENUmutagenized $G_{1}$ male mice, which is paralleled by frozen sperm samples. ${ }^{29,32}$ Oligonucleotide primers (Table 1) were designed to allow amplification of all protein-coding sequences within Nmnatl and used for PCR amplification of the pooled DNA samples. Amplified products were assessed by high-resolution melting curve analysis with the use of the LightScanner platform (Idaho Technology, Salt Lake City, UT). Because of the reduced melting temperature of mismatched nucleotides, ENU-induced mutations are evident as left-shifted melt curves, which are then verified by Sanger sequencing. This approach identified the Nmnat 1 c. $25 \mathrm{G}>\mathrm{A}$ allele (Nmnatl $^{\text {imh }}$, hereafter referred to as Nmnat $1^{V 9 M}$ ), which was subsequently re-derived by in vitro fertilization using cryopreserved sperm (mixed BALB/c and $\mathrm{C} 3 \mathrm{H} / \mathrm{HeH})^{33}$ and wild-type C57BL/6J (B6) oocytes. The subsequent progeny were then bred into the wild-type B6 background. Before data collection, this mouse strain was outcrossed to B6 mice five times to eliminate approximately

Table 1 Set of Oligonucleotide Primer Pairs that Provide Complete Coverage of the Nmnat1 Protein-Coding Sequences for PCR Amplification and Sequencing

\begin{tabular}{|c|c|c|}
\hline Exon & Forward & Reverse \\
\hline 2 & 5'-GGTTGCATGTAGGTCAACAC-3' & 5'-GTCTTTAATTAGCTGGGTCGC-3' \\
\hline 3 & 5'-TAAAGTCTGATTTGTTATGCCTAATATCG-3' & 5'-ACAAGAACATGTGGACTGC-3' \\
\hline 4 & 5'-TCTGACATTAAGGAGTGTGCT-3' & 5'-TTTGGAGTCCTGGTAGACATC- $3^{\prime}$ \\
\hline 5 & 5'-CCTGACCTTGTGCTTGATTC-3' & 5'-TGGTGGACGAGATGTCATT-3' \\
\hline 5 & $5^{\prime}-\mathrm{CAGAGCAACATCCACCT-3^{ \prime }}$ & $5^{\prime}-$ GAGTCTCCAGACGAGCC $-3^{\prime}$ \\
\hline
\end{tabular}

These primers were used in the procedures that led to the identification of the p.V9M-Nmnat1 allele. 
97\% of the ENU-induced mutations. On the basis of the mutation rate of approximately 0.67 mutations/Mbp for ENU mutagenesis and the size of the mouse genome (approximately $\left.2.5 \times 10^{3} \mathrm{Mbp}\right),{ }^{31}$ it would be anticipated that in a mouse where no mutation is being selected for during outcrossing, only approximately 50 induced mutations would remain across the entire genome, of which just one would be expected to be in a coding region. ${ }^{34}$ The chance of one additional coding mutation that is physically linked to the known mutation on mouse chromosome 4 persisting after five outcrosses is $22 \%{ }^{34}$ To further mitigate the possibility of influence from the presence of an unidentified mutation, all experiments were performed on age-matched homozygous mutant Nmnat1 ${ }^{V 9 M}$, heterozygous Nmnat ${ }^{V 9 M}$, and wild-type mice generated by intercrossing heterozygous Nmnat $1^{V 9 M}$ mice.

\section{Identification of Nmnat1 ${ }^{\text {D243G }}$ Mice}

The Nmnat1 ${ }^{\text {tvrm113 }}$ mutant, hereafter referred to as Nmnat1 $^{\text {D243G }}$, was identified in a ${\mathrm{B} 6 \mathrm{G}_{3}}_{3}$ ENU mutagenesis screen from the Translational Vision Research Models $\operatorname{program}^{30}$ at The Jackson Laboratory (Bar Harbor, ME) by indirect ophthalmoscopy. The fundus examination revealed an abnormal retina with pigmentary changes and a grainy appearance with light spots, and this phenotype segregated in a monogenic, recessive manner. The genomic location of the mutation was determined by linkage analysis. Genomic DNA from progeny of an $\mathrm{F}_{2}$ intercross of the mutant strain with DBA/2J (DBA) was extracted as described. ${ }^{35}$ DNA from 10 affected and 10 unaffected $F_{2}$ offspring was pooled and assayed genome-wide with 48 simple sequence length polymorphic markers known to differ between B6 and DBA. Once a map position was identified on chromosome 4 , it was refined in a high-resolution intercross that involved $765 \mathrm{~F}_{2}$ mice of the intercross described.

To identify the causative mutation, a whole mouse exome library was constructed, using fragmented genomic DNA $(1 \mu \mathrm{g})$ to a peak size of $300 \mathrm{bp}$ by sonicating on low power for 30 seconds with power on, 30 seconds with power off for a total of 10 minutes using a Diagenode Bioruptor UCD200TM-EX (Denville, NJ). The precapture paired end library was constructed with the TruSeq DNA Sample Preparation Kit (part number FC-121-100; Illumina, San Diego, CA) with no size selection step and 18 cycles of PCR. The precapture library was hybridized to the Roche NimbleGen Mouse Exome (Reference no. 9999042611) capture probe set (Roche NimbleGen, Madison, WI) according to the manufacturer's instructions. The sequencing library was subjected to real-time quantitative PCR, pooled with two similar libraries, and sequenced on a single lane of an Illumina HiSeq 2000 (Illumina) using a $2 \times 100$ bases (paired end) sequencing protocol. Highthroughput sequence data were sorted with a local JAX Galaxy interface pipeline. ${ }^{36-38}$ Sequence reads were quality assessed using FastQC version 0.5 (Babraham
Bioinformatics, Babraham, UK; http://www.bioinformatics. babraham.ac.uk/projects/fastqc) and aligned to the mouse reference genome $(\mathrm{mm} 10)$ from the University of California Santa Cruz, released December 2011, using BWA version 1.2.3. ${ }^{39}$ PCR duplicates were removed with SAMtools rmdup version 1.0.0. ${ }^{40}$ Single nucleotide polymorphisms and insertions/deletions were called with SAMtools mpileup version 1.0.0, ${ }^{40}$ and genomic and functional annotations were assigned to the variants using SnpEff version 0.9. ${ }^{41}$ Sequence analysis revealed no additional coding variants within the critical chromosomal region. To confirm the identified variant in both the segregating mapping and the maintenance colonies, PCR amplification and analysis were performed. Phenotypic characterization was performed on age-matched B6-Nmnat1 mutant (N5) and B6 control mice.

\section{Mouse Husbandry}

Mice, bred and housed in the Schepens Eye Research Institute (Nmnat $1^{V 9 M}$ mice) and Research Animal Facility at The Jackson Laboratory (Nmnat ${ }^{D 243 G}$ mice), were provided ad libitum $4 \%$ or $6 \%$ fat rodent diet, respectively, and water in a vivarium with a 12-h light/12-h dark cycle. This study conformed to the Association for Research in Vision and Ophthalmology Statement for the Use of Animals in Ophthalmic and Vision Research. All procedures were approved by the Animal Care and Use Committees of the Schepens Eye Research Institute and of The Jackson Laboratory.

\section{Genotyping}

For the Nmnat ${ }^{V 9 M}$ line, genomic DNA was isolated from tissue collected from each mouse with the use of the DNeasy Blood \& Tissue Kit (Qiagen, Hilden, Germany). PCR was then performed with a forward primer $5^{\prime}$-ACGTATTTGCCCACCTGTCT-3' (intron 1) and a reverse primer 5'-TGGGGTTAAAAGAGCCACAG-3' (exon 2) to amplify a 194-bp region of Nmnatl that contained codon nine. The $20-\mu \mathrm{L}$ PCR reactions had final concentrations of $200 \mu \mathrm{mol} / \mathrm{L}$ for each primer, $200 \mathrm{nmol} / \mathrm{L}$ for each of the dNTPs (dATP, dGTP, dTTP, and dCTP), $2 \mathrm{mmol} / \mathrm{L} \mathrm{MgCl}_{2}$, and 1 unit of Hot FirePol DNA polymerase (Solis BioDyne, Tartu, Estonia). The thermocycling protocol was $95^{\circ} \mathrm{C}$ for 14 minutes; 30 cycles of $95^{\circ} \mathrm{C}$ for 45 seconds, $53^{\circ} \mathrm{C}$ for 45 seconds, $72^{\circ} \mathrm{C}$ for 30 seconds; $72^{\circ} \mathrm{C}$ for 7 minutes. The PCR product was subjected to Sanger sequencing, and the electropherograms were analyzed at nucleotide c.25 to identify each mouse as wild-type, heterozygous, or homozygous Nmnat1 $^{V 9 M}$ (Figure 1A).

For Nmnat ${ }^{D 243 G}$ mice, the Nmnatl genomic region that contained the mutation was amplified with the forward primer 5'-GAACGAGTGGATCACCAATGA-3' (exon 5), reverse primer $5^{\prime}$-GCAAGTCCTTCCCTGAGTTT- $3^{\prime} \quad\left(3^{\prime}\right.$ untranslated region), and the NEB taq polymerase kit (New England BioLabs, Ipswich, MA). The 11- $\mu$ L PCR reactions 

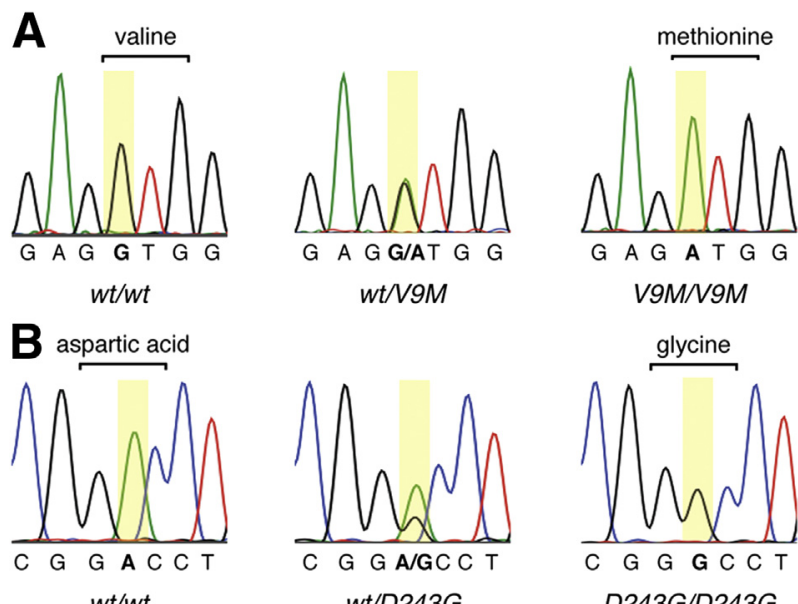

$w t / D 243 G$

$D 243 G / D 243 G$
Figure 1 Identification of the Nmnat1 ${ }^{\text {VgM }}$ and Nmnat1 ${ }^{\text {D243G }}$ mutations by Sanger sequencing of genomic DNA. A: Electropherograms of $w / w, w t /$ $V 9 M$, and V9M/V9M mice, where codon 9 is bracketed and base c.25 is highlighted in yellow. B: Electropherograms of $w / w, w t / D 243 G$, and D243G/ $D 243 G$ mice, where codon 243 is bracketed and base c.728 is highlighted in yellow. D243G/D243G, homozygous Nmnat $1^{D 243 G} ;$ V9M/V9M, homozygous Nmnat $1^{\text {VIM }}$; wt/D243G, heterozygous Nmnat1 ${ }^{D 243 G} ; w t / V 9 M$, heterozygous Nmnat $1^{V g M} ; w / w$, wild-type littermate.

had final concentrations of $180 \mathrm{nmol} / \mathrm{L}$ for each primer, 225 $\mathrm{nmol} / \mathrm{L}$ dNTPs, and 0.55 units of Taq DNA polymerase. The thermocycling protocol was $97^{\circ} \mathrm{C}$ for 3 minutes; 40 cycles of $95^{\circ} \mathrm{C}$ for 15 seconds, $55^{\circ} \mathrm{C}$ for 15 seconds, $72^{\circ} \mathrm{C}$ for 30 seconds; $72^{\circ} \mathrm{C}$ for 3 minutes. The 278 -bp PCR product was subjected to Sanger sequencing, and concordance of the retinal phenotype with the $A>G$ transition at c.727 was assessed (Figure 1B).

Both mutant Nmnatl lines were found to be negative for the $\mathrm{Crbl}^{\text {rd8 }}$ mutation. $^{42}$

\section{Electroretinography}

After having been dark-adapted overnight, each mouse was anesthetized by intraperitoneal injection of ketamine and xylazine diluted in sterile saline, and the eyes were dilated by topical application of $1 \%$ tropicamide (Nmnat ${ }^{V 9 M}$ mice) or $1 \%$ atropine sulfate (Nmnat $1^{D 243 G}$ mice) approximately 10 minutes before data collection. The mice were placed on a heated stage to maintain body temperature, and a gold ring electrode (Diagnosys, Lowell, MA) was gently placed on the center of each cornea with a small application of ophthalmic lubricant. Full-field ERGs were recorded simultaneously from both eyes in response to 4-ms broadband stimuli with the use of the ColorDome Ganzfeld system (Diagnosys). For Nmnat1 ${ }^{V 9 M}$ mice, ERGs were collected from 7 to 10 mice per genotype at 1, 2, 3, 4, 7.5, and 10 months of age, and for Nmnat ${ }^{D 243 G}$ mice, ERGs were collected across 12 months from three to seven mice per genotype per time point. The stimulus parameters used to test each mouse line (described in the next paragraph) were selected independently at the respective testing facility; however, both sets of parameters generate responses from the target class(es) of photoreceptors. As in all experiments described here, both male and female mice were tested.

In dark-adapted Nmnat $I^{V 9 M}$ mice, rod-driven ERGs were recorded in response to a $0.01 \mathrm{~cd} . \mathrm{s} / \mathrm{m}^{2}$ light stimulus (10 flashes at $0.2 \mathrm{~Hz}$ ), and mixed rod/cone ERGs were recorded in response to a $10 \mathrm{~cd} . \mathrm{s} / \mathrm{m}^{2}$ light stimulus (three flashes at $0.03 \mathrm{~Hz}$ ). For dark-adapted Nmnat1 ${ }^{D 243 G}$ mice, rod-driven ERGs were recorded in response to a $0.006 \mathrm{~cd} . \mathrm{s} / \mathrm{m}^{2}$ light stimulus (5 flashes at $0.1 \mathrm{~Hz}$ ), and mixed rod/cone ERGs were recorded in response to a $0.25 \mathrm{~cd} . \mathrm{s} / \mathrm{m}^{2}$ stimulus (five flashes at $0.1 \mathrm{~Hz}$ ). Next, mice were light-adapted by exposure to a steady, rod-suppressing background light that was set to $5 \mathrm{~cd} / \mathrm{m}^{2} 43,44$ for the NmnatI ${ }^{V 9 M}$ mice and $110 \mathrm{~cd} / \mathrm{m}^{2}$ for the Nmnat $1^{D 243 G}$ mice. This background light then remained on during the acquisition of cone-driven ERGs that were recorded in response to a $20 \mathrm{~cd} . \mathrm{s} / \mathrm{m}^{2}$ light stimulus (20 flashes at $0.5 \mathrm{~Hz}$ ) for the Nmnat ${ }^{\mathrm{V} 9 M}$ mice and a 10 cd.s $/ \mathrm{m}^{2}$ light stimulus (10 flashes at $1 \mathrm{~Hz}$ ) for the Nmnat1 ${ }^{D 243 G}$ mice.

For all conditions, the magnitude of the ERG b-wave was measured as the absolute voltage change from the trough of the a-wave (or from the voltage measured at the expected implicit time of that trough, should the a-wave be undetectable) to the b-wave peak. ${ }^{45}$ The a-wave was measured as the absolute voltage change from prestimulus baseline to the initial post-stimulus trough. ${ }^{46}$ Analysis of the a-wave is reported for brighter stimulus intensities (ie, $0.25 \mathrm{~cd} . \mathrm{s} / \mathrm{m}^{2}$ and $10 \mathrm{~cd} . \mathrm{s} / \mathrm{m}^{2}$ ) in the dark-adapted condition for which this component of the ERG is robust in normal mice, as opposed to light-adapted ERGs ${ }^{47}$ and $\operatorname{dim}$ (ie, $0.006 \mathrm{~cd} / \mathrm{m}^{2}$ and 0.01 $\mathrm{cd} / \mathrm{m}^{2}$ ) dark-adapted ERGs. ${ }^{48}$ For the Nmnat1 ${ }^{V 9 M}$ line, a one-way analysis of variance was used for a multiple comparison across genotypes, and post hoc testing was performed with the two-tailed, unpaired $t$-test for which only $P$ values $<0.0167$ were considered significant after Bonferroni correction. The two-tailed, unpaired $t$-test was used to determine significance for the Nmnat1 $1^{\text {D243G }}$ line.

\section{In Vivo Retinal Imaging}

Anesthesia and dilation procedures were as described in the section above for electroretinography. Images were collected at $0.75,1,2,3,4,8,10$, and 15 months of age in the Nmnat ${ }^{V 9 M}$ mice and at ages up to 12 months in the Nmnat ${ }^{D 243 G}$ mice. Fundus images were acquired with the Micron retinal imaging microscope system (Phoenix Biosystems, Pleasanton, CA) and StreamPix software version 5.8.1.4 (NorPix, Montreal, Canada). The Micron model III was used for assessing the Nmnat ${ }^{V 9 M}$ mice, and model IV was used for assessing the Nmnat1 ${ }^{D 243 G}$ mice. GenTeal lubricating ointment was applied to the cornea to minimize light refraction between the eye and microscope objective.

Cross-sectional retinal images were acquired with the InVivoVue OCT system (Bioptogen, Morrisville, NC). Both eyes from 7 to 10 mice from each genotype were tested at 
each time point for the Nmnat ${ }^{V 9 M}$ line, with the exception of 15 months when five mice were tested per genotype, whereas one eye from four or five mutant or three to eight B6 mice was tested at each age for the Nmnat1 ${ }^{\text {D243G }}$ line. For both mouse lines, a rectangular OCT volume centered on the optic nerve head was captured, and a B-scan located approximately $200 \mu \mathrm{m}$ ventral to the $\mathrm{ONH}$ was selected for measurement. Retinal thickness was measured as the distance between the nerve fiber layer and the hyporeflective boundary between the retinal pigment epithelium (RPE) and choroid. Significance testing of the data was performed as described in the section above for electroretinography.

\section{Ex Vivo Retinal Imaging}

\section{Nmnat ${ }^{\text {VgM }}$ Mice}

Mice were euthanized with a lethal dose of Euthasol (Virbac, Fort Worth, TX), and tissues were fixed by intracardiac perfusion with the use of a Masterflex peristaltic pump (ColeParmer, Vernon Hills, IL). Each mouse was perfused first with $0.13 \mathrm{~mol} / \mathrm{L}$ phosphate-buffered saline (PBS) $\mathrm{pH} 7.2$ to 7.4 that contained $2 \mathrm{U}$ heparin/mL until the perfusate became clear, then with approximately $30 \mathrm{~mL}$ of $4 \%$ paraformaldehyde in PBS, followed by approximately $30 \mathrm{~mL}$ of one-half Karnovsky's fixative (2\% paraformaldehyde and $2.5 \%$ glutaraldehyde in $0.1 \mathrm{~mol} / \mathrm{L}$ sodium cacodylate buffer, $\mathrm{pH}$ 7.4). All solutions were warmed to approximately $37^{\circ} \mathrm{C}$ at the time of perfusion, and the rate of injection was approximately $6.7 \mathrm{~mL} / \mathrm{min}$. Immediately after perfusion, each eye was marked for orientation with permanent ink and enucleated. After 1 hour of post-fixation in one-half Karnovsky's fixative, the anterior segment was removed, and the eye cup was further post-fixed overnight and then washed three times with sodium cacodylate buffer. Next, the eyecup was incubated with $2 \%$ osmium tetroxide, dehydrated with graded ethyl alcohol solutions, and blocked in epoxy resin.

Eyes were sectioned and prepared for both light microscopy and transmission electron microscopy (TEM). For light microscopy, semithin $(1 \mu \mathrm{m})$ transverse sections were cut at the level of the optic nerve head so that each slice contained the temporal and nasal retina. The sections were stained with $1 \%$ toluidine blue in $1 \%$ sodium tetraborate aqueous solution and imaged with an Eclipse Ti microscope (Nikon, Tokyo, Japan). Two mice (one eye each) per genotype at the same time points described in In Vivo Retinal Imaging were analyzed, with the exception that three mice per genotype were evaluated at 15 months. Images were acquired from the nasal retina with the use of a $20 \times$ open air objective with a DS-Fi1 camera (Nikon ) set to $1.5 \times$ optical zoom. For specimens from the 1-, 4-, and 15-month time points, ultrathin sections (60 to $90 \mathrm{~nm}$ ) were cut from the epoxy blocks using an EM UC7 ultra-microtome (Leica Microsystems, Buffalo Grove, IL), stained with uranyl acetate and Sato's lead citrate stain, and then imaged by TEM using a Tecnai G2 Spirit transmission electron microscope (FEI, Hillsboro, OR) and AMT XR41 digital CCD camera
(Advanced Microscopy Techniques, Woburn, MA). For some light microscopy and TEM images, an additional brightness/contrast adjustment was made with Photoshop (Adobe Systems, Mountain View, CA).

Tissue preparation and immunofluorescence analyses on sagittal vibratome sections was performed as described previously, ${ }^{49}$ with the exceptions that the mice were euthanized by carbon dioxide asphyxiation, eye orientation was marked with a mild corneal burn with the use of a small vessel cauterizer (Fine Scientific Tools, Foster City, CA), and Fluoromount $\mathrm{G}$ was used as the slide mounting medium. Images were acquired from the ventral retina using a Leica SP5 confocal microscope (Leica Microsystems), and $10-\mu \mathrm{m}$ Z-stacks $(0.5-\mu \mathrm{m}$ spacing between image slices $)$ were assembled in ImageJ version $1.50 \mathrm{~g}(\mathrm{NIH}$, Bethesda, $\mathrm{MD})$. Final images were generated by brightest point projection and sharpened with the Unsharp Mask function (1.0 pixel radius, 0.3 mask weight).

\section{Nmnat1 ${ }^{\text {D243G }}$ Mice}

Tissue preparation for light microscopy was performed as previously described ${ }^{50}$ in three or four mice per genotype at ages 1, 3, 6, 9, and 12 months. Briefly, after carbon dioxide asphyxiation, eyes were enucleated and placed in cold acetic acid/methanol solution overnight at $4{ }^{\circ} \mathrm{C}$. The eyes were then embedded in paraffin, sectioned at $5 \mu \mathrm{m}$, stained with hematoxylin and eosin, and examined under light microscopy. Slides were scanned with a NanoZoomer 2.0HT (Hamamatsu, Japan) at $40 \times$ magnification with the use of a $20 \times$ objective and $2 \times$ digital zoom. Post-acquisition processing was completed with Fiji ${ }^{51}$ with images taken within $500 \mu \mathrm{m}$ on either side of the optic nerve head for each sample and sharpened with the Unsharp Mask function (1.0 pixel radius, 0.7 mask weight). Three to five independent samples were assessed for each time point.

For immunofluorescence, eyes were enucleated and fixed overnight in cold methanol/acetic acid/phosphate-buffered solution $(3: 1: 4 \mathrm{v} / \mathrm{v} / \mathrm{v})$. Tissues were then dehydrated, paraffin-embedded, and sliced into $5-\mu \mathrm{m}$ sections before being deparaffinated and blocked with normal donkey serum (Jackson ImmunoResearch, West Grove, PA). The primary antibodies used were goat anti-S-opsin (sc-14363; Santa Cruz Biotechnology, Santa Cruz, CA) and rabbit anti-M/Lopsin (AB5405; Millipore, Billerica, MA), both diluted 1:200. After overnight incubation in primary antibody at $4^{\circ} \mathrm{C}$, the sections were washed in PBS and incubated with secondary antibodies for 1 hour at room temperature. The secondary antibody for the S-opsin antibody was Alexa Fluor 488-labeled donkey anti-goat IgG (Life Technologies, Carlsbad, CA), and the secondary antibody for the L/M-opsin antibody was cyanine 3-labeled donkey anti-rabbit IgG (Jackson ImmunoResearch), both diluted 1:200. Specimens were stained with DAPI nuclear stain, washed several times in PBS, and mounted in Vectashield anti-fade medium (Vector Laboratories, San Mateo, CA). Fluorescent staining was visualized with a DMLB upright microscope (Leica 
Microsystems) with the use of the QImaging camera system (QImaging, Surrey, BC, Canada).

TEM analysis was performed on 1-month-old eyes that were fixed and dissected as previously described. ${ }^{52}$ The tissue was then post-fixed in osmium tetroxide, dehydrated, embedded in plastic, and sectioned. Ultrathin sections were stained with uranyl acetate and lead citrate and then imaged with a JEM-1230 (JEOL, Tokyo, Japan) transmission electron microscope.

\section{Pupillary Light Response}

Video clips of pupil constriction in response to the onset of steady light exposure were recorded with the Micron retinal imaging microscope system (model III for Nmnat ${ }^{V 9 M}$ mice; model IV for Nmnat ${ }^{D 243 G}$ ) and built-in light source. The light stimulus was set to approximately $50 \%$ of the maximum brightness (approximately 60,000 lux) without filters. In Fiji, single frames from the Nmnat1 ${ }^{D 243 G}$ recordings were cropped, sharpened with Unsharp Mask (radius 1, mask weight 0.8), and contrast enhanced with Enhance Local Contrast with the use of default settings, except for a maximum slope of 2.00 .

\section{Results}

The Nmnat ${ }^{V 9 M}$ and Nmnat $1^{D 243 G}$ mice were generated by ENU mutagenesis, as described in Materials and Methods. Neither homozygous Nmnat1 ${ }^{V 9 M}$ nor Nmnat1 ${ }^{D 243 G}$ mice presented an extraocular phenotype. Size, weight, activity level, motor coordination, breeding success, and life expectancy were normal.

\section{Loss of Retinal Function in Nmnat1 Mutant Mice}

Measurements of retinal function with the use of electroretinography showed that both Nmnat ${ }^{V 9 M}$ and Nmnat $1^{D 243 G}$ mutant mice experienced rapid loss of rod and cone function. Rod-driven, mixed rod/cone, and conedriven ERGs were collected at 1, 2, 3, 4, 7.5, and 10 months from wild-type, heterozygous, and homozygous Nmnat ${ }^{V 9 M}$ mice littermates (Figure 2). In all three stimulus conditions, the b-wave measurements in wild-type and heterozygous Nmnat1 ${ }^{V 9 M}$ littermates were statistically equivalent (two-tailed, unpaired $t$-test) at every time point, and both sets of mice show an age-dependent decrease that was consistent with previous studies. ${ }^{49,53,54}$ Although the responses in homozygous Nmnat $1^{V 9 M}$ mice were decreased by approximately $35 \%$ at 1 month in both dark-adapted conditions (rod-driven and mixed rod/cone) and by $40 \%$ in the light-adapted condition, these difference were not statistically significant (one-way analysis of variance, $P=0.06$ for rod-driven ERG; $P=0.14$ for mixed $\mathrm{rod} / \mathrm{cone}$ ERG, $P=0.03$ for cone-driven ERG). By 2 months, the decrements in the rod-driven, mixed rod/cone, and conedriven ERGs in homozygous Nmnat1 ${ }^{V 9 M}$ mice were
$>70 \%\left(P=1.8 \times 10^{-7}, 3.8 \times 10^{-6}\right.$, and $3.1 \times 10^{-8}$, respectively), and by 4 months, ERGs were undetectable across all conditions. Homozygous Nmnat1 ${ }^{D 243 G}$ mice also showed greatly reduced retinal function in comparison with age-matched wild-type B6 mice in rod-driven $(-72 \%$, unpaired $t$-test: $\left.P=1.6 \times 10^{-3}\right)$, mixed rod/cone $(-87 \%$, unpaired $t$-test: $\left.P=3.3 \times 10^{-7}\right)$, and cone-driven $(-71 \%$, unpaired $t$-test: $P=1.7 \times 10^{-4}$ ) conditions by 12 months; this occurred along a slower time scale than for homozygous Nmnat ${ }^{V 9 M}$ mice (Supplemental Figure S1).

To directly confirm the loss of photoreceptor function, the a-wave was measured in the dark-adapted ERGs generated in response to the $10-\mathrm{cd} . \mathrm{s} / \mathrm{m}^{2}$ stimulus for the Nmnat $1^{V 9 M}$ mice and the $0.25-\mathrm{cd} . \mathrm{s} / \mathrm{m}^{2}$ stimulus for the Nmnat1 ${ }^{\text {D243G }}$ mice. Although the a-wave was not significantly different across genotypes in the Nmnat1 ${ }^{V 9 M}$ line at 1 month (oneway analysis of variance, $P=0.06$ ), it was decreased in homozygous Nmnat $1^{V 9 M}$ mice by $91 \%\left(P=1.0 \times 10^{-10}\right)$ in comparison with the wild-type and heterozygous littermates at 2 months (Figure 2). By 4 months, the a-wave was absent in homozygous Nmnat $1^{V 9 M}$ mice, as was the b-wave. The a-waves of the Nmnat $1^{D 243 G}$ homozygous mutant and B6 wild-type control mice were equivalent (unpaired $t$-test, $P=0.86$ ) at 1 month (Supplemental Figure S1). However, the a-wave of the homozygous mutant mice declined rapidly between 3 and 4 months, and by 12 months, this component of the ERG was decreased by $83 \%\left(P=7.4 \times 10^{-5}\right)$ in comparison with that of the control mice.

\section{Retinal Degeneration in Nmnat1 Mutant Mice}

In vivo retinal imaging of heterozygous and homozygous Nmnat $1^{V 9 M}$ mice and wild-type littermates at $0.75,1,2,3,4$, 8,10 , and 15 months of age showed a progressive and severe chorioretinal degeneration. The representative pairs of fundus and OCT images shown for each time point in Figure $3 \mathrm{~A}$ were collected from the same retina; images from heterozygous Nmnat $1^{V 9 M}$ mice are not presented because they were indistinguishable from those of the wild-type littermates. At 3 weeks, the fundus and OCT images from homozygous Nmnat ${ }^{V 9 M}$ mice appeared normal. However, despite an unremarkable fundus image at 1 month, the retina was noticeably thinner, particularly at the level of the photoreceptors. By 2 months, retinal vasculature was attenuated, and by 3 months, there was evidence of optic atrophy. At 4 months, OCT showed an advanced degeneration of the photoreceptor layer, and the polygonal lattice of the RPE could be seen through the remaining neural retina in the fundus image. By 8 months, RPE degeneration was suggested by depigmented patches that spread to cover much of the retina in the 10- and 15-month-old mice. Similar changes in retinal morphologic structure occurred in homozygous Nmnat $1^{D 243 G}$ mice (Figure 3B) but at a slower rate.

The progressive retinal thinning in the homozygous Nmnat $1^{\mathrm{V} 9 \mathrm{M}}$ and Nmnat $1^{\text {D243G }}$ mice was quantified by 

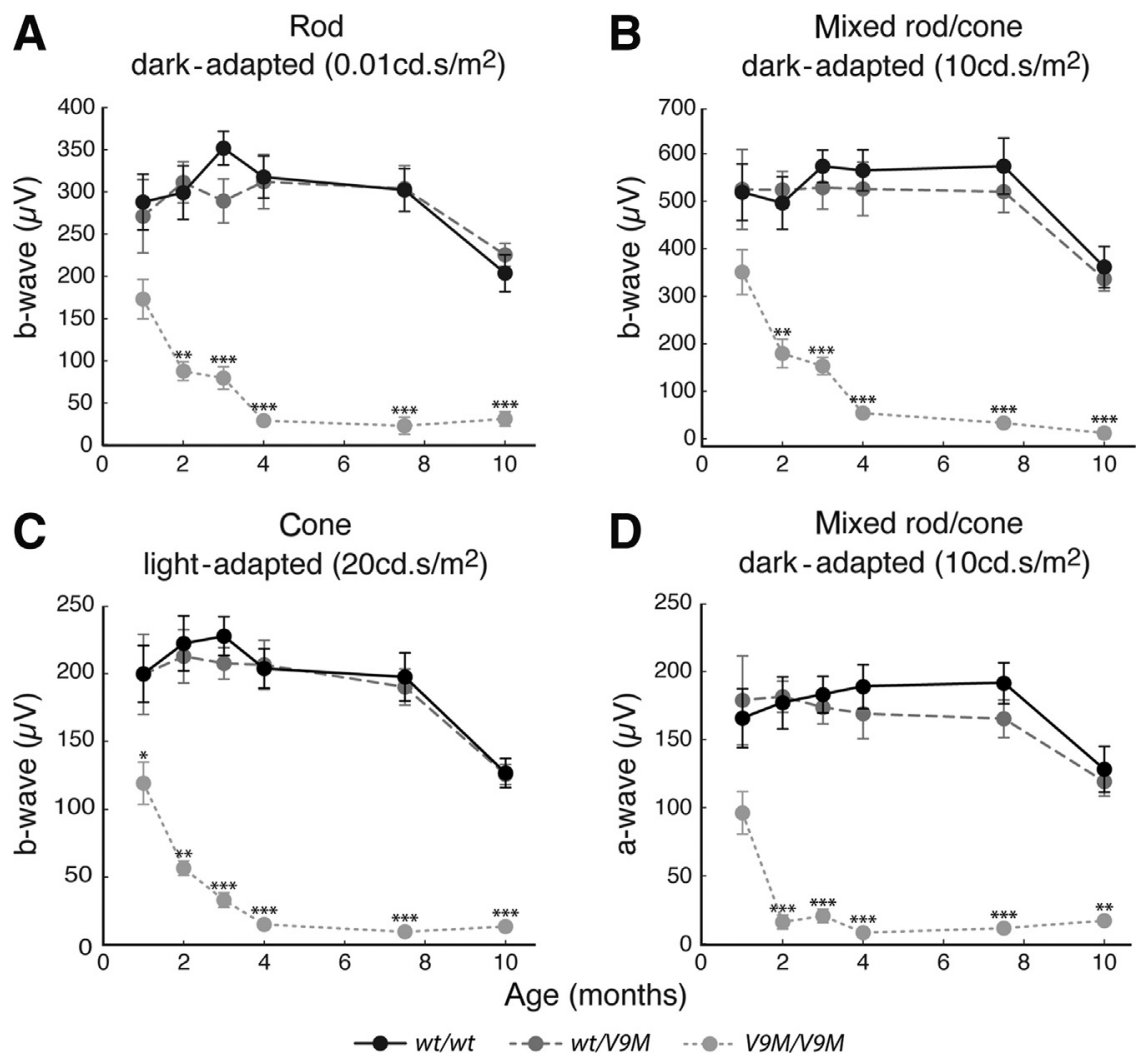

B Mixed rod/cone dark-adapted $\left(10 \mathrm{~cd} . \mathrm{s} / \mathrm{m}^{2}\right)$

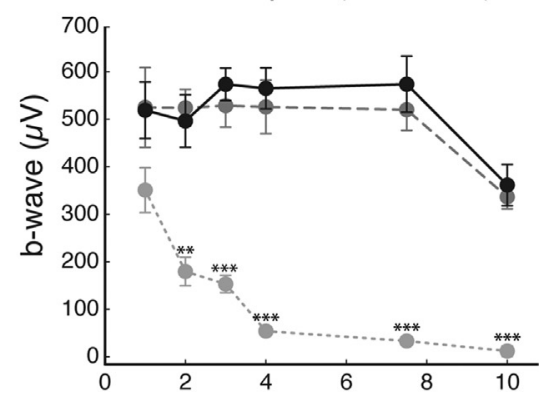

D
Figure 2 Retinal function declines with age in $V 9 M / V 9 M$ mice. ERG data from $w t / w t, w t / V 9 M$, and V9M/V9M mice across 10 months. A-C: B-wave measurements from rod (A), mixed rod/cone (B), and cone (C) ERGs that were generated with fullfield, broadband stimuli $(4 \mathrm{~ms})$ at $0.01 \mathrm{~cd} . \mathrm{s} / \mathrm{m}^{2}$ (dark-adapted), $10 \mathrm{~cd} . \mathrm{s} / \mathrm{m}^{2}$ (dark-adapted), and $20 \mathrm{~cd} . \mathrm{s} / \mathrm{m}^{2}$ (light-adapted), respectively. D: A-wave measurements from the mixed rod/cone condition. Data are expressed as means \pm SEM. ${ }^{*} P<0.05, * * P<0.01$, and $* * * P<0.001$. ERG, electroretinogram; V9M/V9M, homozygous Nmnat1 ${ }^{\text {VIM }}$; wt/V9M, heterozygous Nmnat ${ }^{\text {V }}{ }^{\text {; }}$; $w t / w t$, wild-type littermate. measuring the distance from the nerve fiber layer to the RPE. Although the retinal thickness remained stable in wildtype littermates and heterozygous $N$ mnat ${ }^{V 9 M}$ mice, loss of retinal structure in homozygous Nmnat1 ${ }^{V 9 M}$ mice was especially rapid during the first 4 months of life (Figure 3C). Normal retinal thickness was observed in 3-week-old homozygous Nmnat1 ${ }^{V 9 M}$ mice (one-way analysis of variance, $P=0.78$ ), but 1 week later, the retinas were approximately $18 \%$ thinner than those of the littermate controls $\left(P=5.1 \times 10^{-12}\right)$. Retinal thickness in homozygous Nmnat $1^{V 9 M}$ mice was then reduced by approximately $35 \%\left(P=1.1 \times 10^{-29}\right)$ at 2 months, approximately $45 \%$ $\left(P=1.7 \times 10^{-38}\right)$ at 4 months, and approximately $57 \%$ $\left(P=1.6 \times 10^{-26}\right)$ at 15 months. In contrast, the retinas of homozygous Nmnat1 $1^{D 243 G}$ mice were not significantly thinner than wild-type at 1 month (unpaired, two-tailed $t$-test, $P=0.07)$, and were $47 \%\left(P=1.5 \times 10^{-6}\right)$ thinner than normal at 12 months (Figure $3 \mathrm{C}$ ).

The in vivo retinal imaging results were corroborated by retinal histology. Light microscopy of toluidine bluestained, semithin sections showed progressive retinal degeneration in homozygous Nmnat $1^{V 9 M}$ mice across 15 months, whereas the morphologic structure of both wildtype littermates and heterozygous Nmnat $1^{V 9 M}$ retinas remained unchanged (Figure 4A). Although homozygous Nmnat $1^{V 9 M}$ retinas appeared normal at 3 weeks, the photoreceptor outer segment layer and outer nuclear layer showed thinning at 1 month and nearly complete degeneration by 4 months; only one row of photoreceptor nuclei was visible in the representative image. The inner nuclear layer, which contains the bipolar cell nuclei, maintained a normal appearance for the first several months but then became increasingly disorganized and thinner by 15 months. Similarly, the RPE was morphologically normal for at least the first 4 months of life, but by month 8 there were patches that had degenerated entirely (Figure 4A). These areas in which the RPE was absent were consistent with the pigmentation pattern observed in the fundi of older mice (Figure 3). A similar, albeit more gradual, outer retinal degeneration was observed in homozygous Nmnat $^{\text {D243G }}$ mice (Figure 4B). Although neither ex vivo nor in vivo imaging data established whether development was completely normal in the mutant Nmnat1 retina, ERG data (Loss of Retinal Function in Nmnat1 Mutant Mice) and immunolabeling of the cone opsins (Supplemental Figure S2) confirmed that these retinas developed and had function.

TEM imaging further validated the results from light microscopy. A decrease in photoreceptor outer segment length was evident at 1 month of age in the homozygous Nmnat $1^{\text {V9M }}$ mice (Figure 5A), and regions of RPE cell degeneration were evident at 15 months (Figure 5B). In places where the RPE remained, the apical processes that would ordinarily interdigitate with the photoreceptor outer segments were coiled, and the basal infoldings had been largely replaced by basal deposits. In 1-month-old homozygous Nmnat1 $1^{D 243 G}$ mice, 


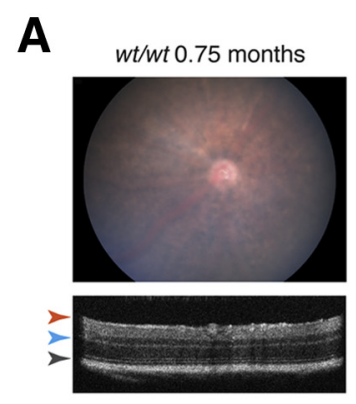

V9MNVM 4 months
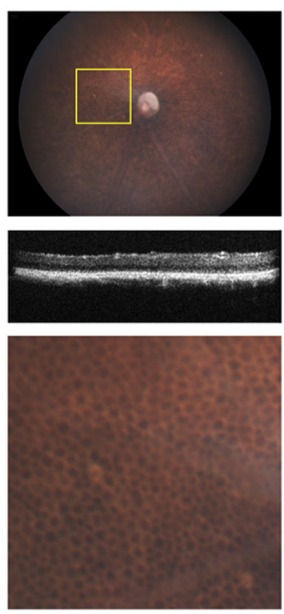

B
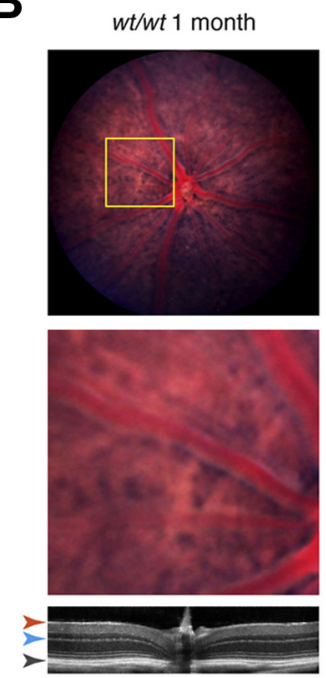

C

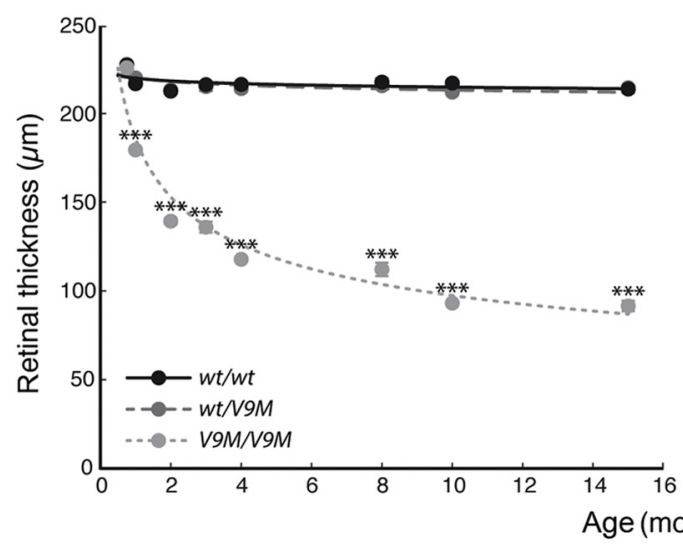

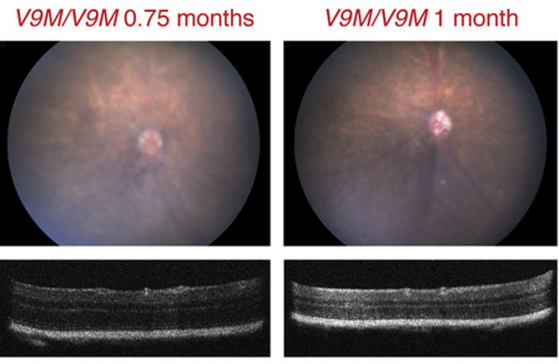

V9M/V9M 8 months
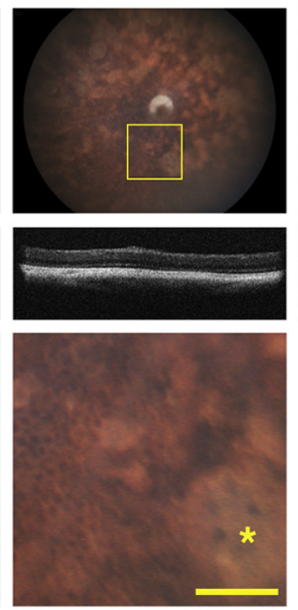

D243G/D243G 1 mont
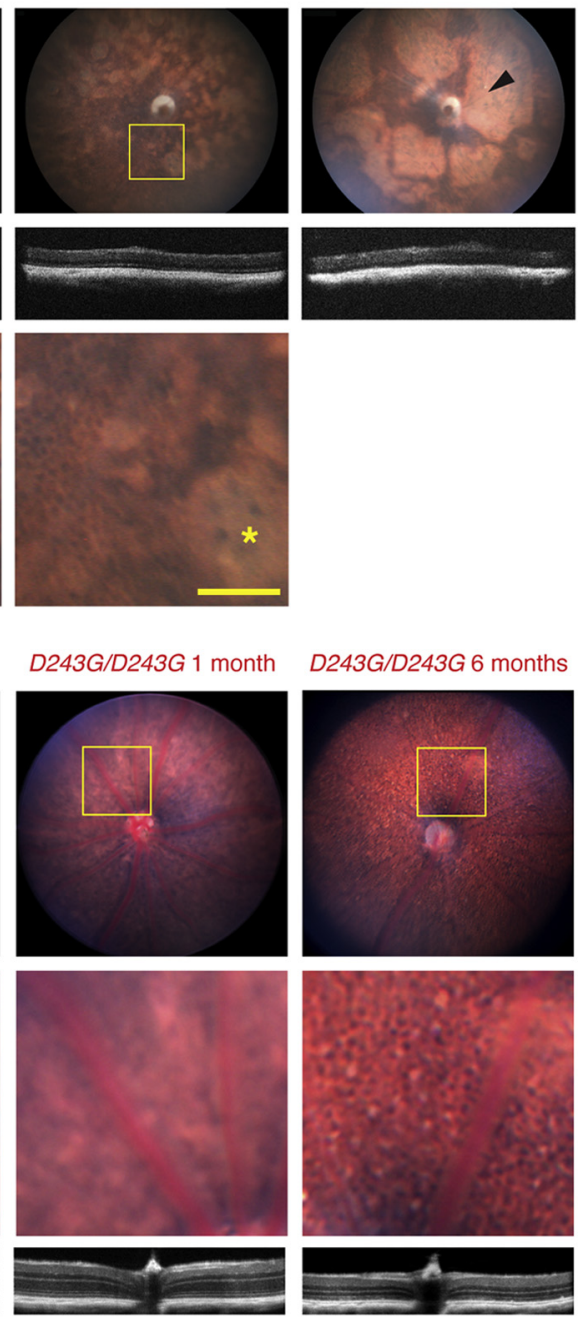

V9MN $9 M 2$ months

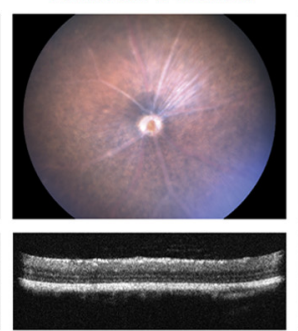

V9M V9M 15 months
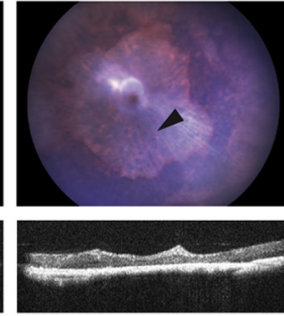

D243G/D243G 6 months $D 243 G / D 243 G 12$ months
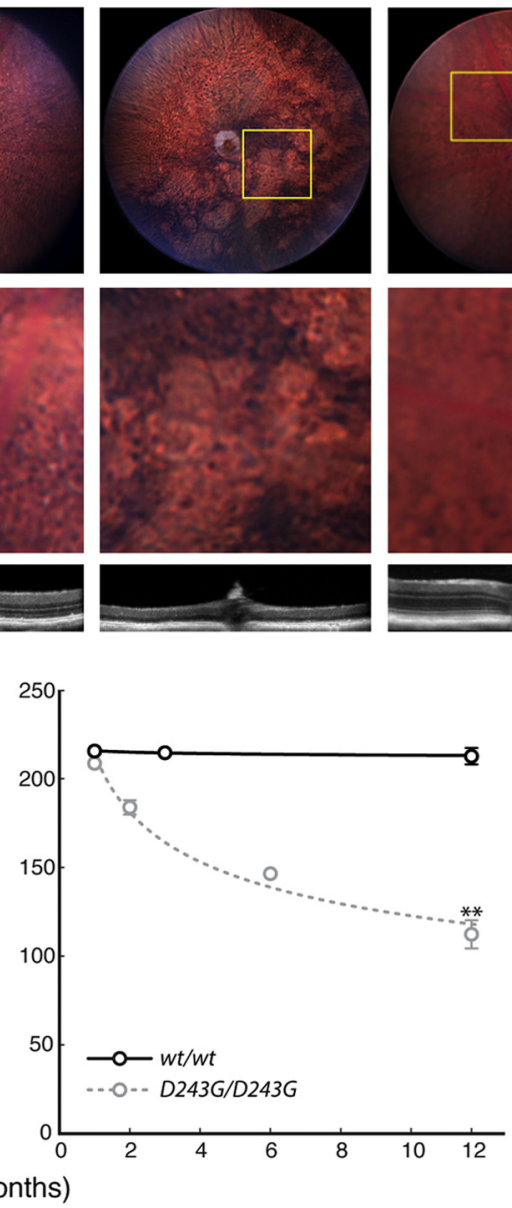

V9MN9M 3 months

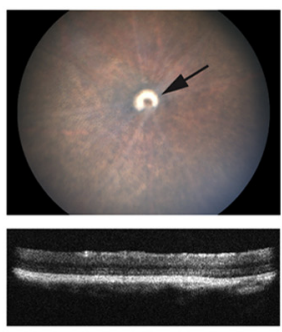

$w t / w t 15$ months
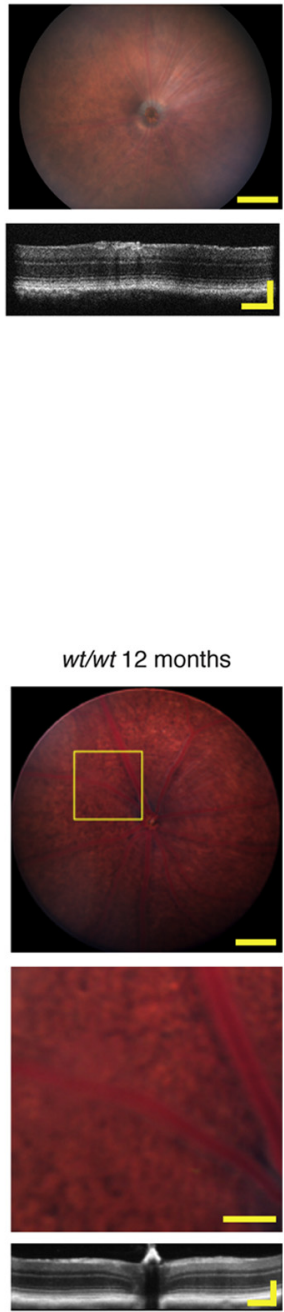

$w t / w t 12$ months

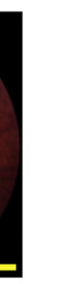


the photoreceptor outer segments and RPE had a normal appearance (Supplemental Figure S3).

\section{Amaurosis in Nmnat1 Mutant Mice}

Although the ERG revealed a complete loss of outer retinal function for homozygous Nmnat ${ }^{V 9 M}$ mice, these measurements did not specifically assess inner retinal cell function. Because photoreceptors and intrinsically photosensitive ganglion cells ordinarily contribute to the pupillary light response, the intrinsically photosensitive ganglion cells could be evaluated functionally by observing this reflex after photoreceptor degeneration. In advanced cases, homozygous Nmnat $1^{V 9 M}$ mice were found to have attenuated pupillary constriction in response to light, whereas wildtype littermates and heterozygous Nmnat1 ${ }^{V 9 M}$ mice maintained normal pupillary light responses (Figure 6). This aspect of the phenotype was observed as early as 11.5 months of age. No homozygous Nmnat ${ }^{D 243 G}$ mice were identified as having lost the pupillary light response during the first 15 months of life (Supplemental Figure S4), which is consistent with a slower progression of retinal degeneration, relative to the homozygous Nmnat ${ }^{V 9 M}$ mice.

\section{Discussion}

The retinal degenerative phenotype in both homozygous Nmnat $^{\text {V9M }}$ and Nmnat $1^{\text {D243G }}$ mice follows a monogenic recessive inheritance pattern without exception, showing a clear causal connection between the mutant Nmnat1 alleles and disease. This early-onset chorioretinal degeneration fully recapitulates key aspects of human NMNATI-LCA in that there is a severe loss of retinal function associated with widespread thinning of the retina which is first observed at the level of the photoreceptor cells, followed by attenuation of retinal vasculature, optic atrophy, and a nonuniform degeneration of the RPE. This RPE phenotype may directly correspond to the atrophic macular lesions with RPE loss that is observed in patients. ${ }^{1,8-10}$ To our knowledge, the homozygous Nmnat $1^{V 9 M}$ line is the only LCA mouse model that has been shown to develop pupillary amaurosis, a feature of all genetic forms of $\mathrm{LCA}^{2}$ that arises from the loss of photoreceptor and intrinsically photosensitive ganglion cell function. ${ }^{5,6,55-57}$ As in human patients, the disease in mice appears to be confined to the retina. Affected animals are otherwise healthy, are of normal size and weight, show normal levels of activity and motor coordination, breed normally, and live equally as long as their littermates; this implies that NMNAT1 serves an especially important role in the retina.

Because these mouse models were generated and discovered in ENU-mutagenesis screens, confirming that the phenotype is caused entirely by each mutation under investigation is difficult. Another unknown genetic variant that persists even after multiple outcrosses with wild-type mice could affect the results. ${ }^{31,34}$ This study accounts for that concern in two complementary ways. First, the homozygous Nmnat1 ${ }^{V 9 M}$ mice were always compared with littermate controls, which would be expected to harbor the same additional variants. Second, having been generated independently greatly reduces the likelihood that the Nmnat $1^{V 9 M}$ and Nmnat $1^{D 243 G}$ lines would share the same secondary ENU-induced mutations. The chance of both mouse lines harboring an additional, physically linked mutation that causes or contributes to the phenotype is low.

In both homozygous Nmnat1 $1^{V 9 M}$ and Nmnat1 ${ }^{D 243 G}$ mutant mice, degeneration occurs after retinal development. Data collected from these mice suggest that photoreceptors are most vulnerable to disruptions in NMNAT1 because they are the first cell type to show signs of disease, with shortening of outer segments evident at 1 month in the homozygous Nmnat ${ }^{V 9 M}$ mice. In both mouse lines, the loss of photoreceptor cell nuclei is precipitous and appears to precede the changes observed in other retinal cell types. Photoreceptors may be hypersensitive to decreased levels of nuclear $\mathrm{NAD}^{+}$because of their extremely high metabolic activity. ${ }^{58-60}$ Recent work has shown that a mutation in NMNAT1 which changes the charge of a critical amino acid residue likely destabilizes the secondary protein structure when stressed by heat shock, ${ }^{27}$ and environmental challenges in cells with high metabolic activity could potentially trigger a similar effect. The metabolic demands of light exposure after eye opening ${ }^{61}$ that require processes supported by NMNAT1 may overwhelm mutant photoreceptors, which is consistent with these cells degenerating after development. This idea is supported by data from Drosophila, showing that photoreceptor degeneration caused by a loss of the nmnat protein can be significantly reduced by blocking phototransduction. ${ }^{21}$ Although to a lesser extent than photoreceptors, homozygous Nmnat1 ${ }^{\text {VMM }}$

\footnotetext{
Figure 3 In vivo retinal imaging shows rapid and severe chorioretinal degeneration. A: Representative pairs of fundus and 0CT images from the Nmnat1 ${ }^{\text {VM }}$ mouse line across 15 months at ages indicated. Optic atrophy is evident at 3 months (black arrow). Boxed areas are shown at higher magnification below. Bottom row: At 4 months, the polygonal lattice of the RPE is visible, and at 8 months, regions of RPE degeneration are observed (asterisk). Larger regions of RPE degeneration are indicated with black arrowheads in the images at 10 and 15 months. B: Representative pairs of fundus and OCT images from the Nmnat $1^{D 243 G}$ and control mice across 12 months. Boxed areas are shown at higher magnification below. C: Retinal thickness at different ages, measured as the distance from the nerve fiber layer to the RPE (orange arrow and gray arrow, respectively, in images in $\mathbf{A}$ and $\mathbf{B}$ ). The left panel shows measurements for wt/ $w t, w t / V 9 M$, and V9M/V9M mice. The right panel shows measurements for B6 and D243G/D243G mice. The initial loss of retinal thickness is due to outer retinal degeneration; region between the blue and gray arrows in images in $\mathbf{A}$ and $\mathbf{B}$. Data are expressed as means \pm SEM. ${ }^{* *} P<0.01, * * * P<0.001$. Scale bars: approximately $100 \mu \mathrm{m}$ (magnified images); approximately $150 \mu \mathrm{m}$ (OCT images, $\mathrm{x}$ and y dimensions); approximately $250 \mu \mathrm{m}$ (fundus images). D243G/D243G, homozygous Nmnat1 ${ }^{D 243 G}$; RPE, retinal pigment epithelium; V9M/V9M, homozygous Nmnat1 ${ }^{\text {V9M }}$; wt/V9M, heterozygous Nmnat ${ }^{\text {V9M }}$; wt/wt, wildtype.
} 

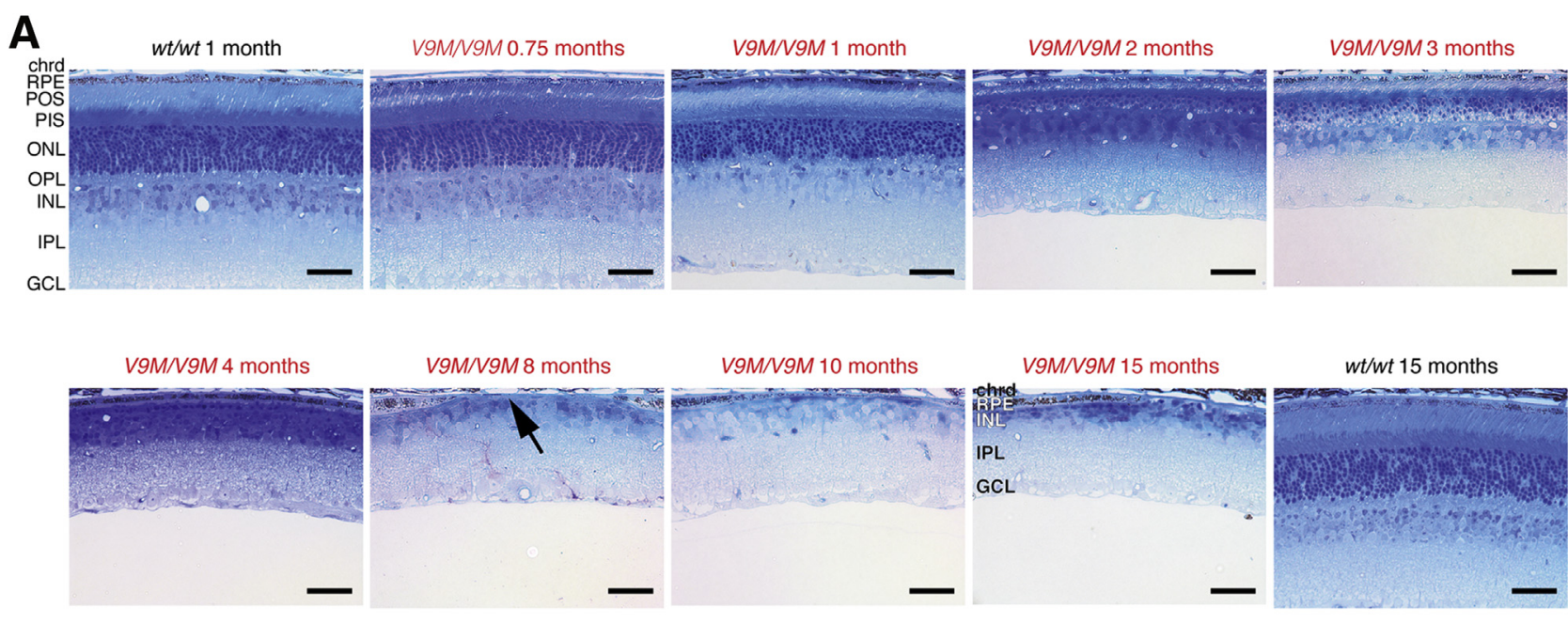

V9MN9M 15 months

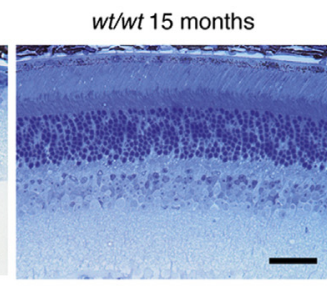

B

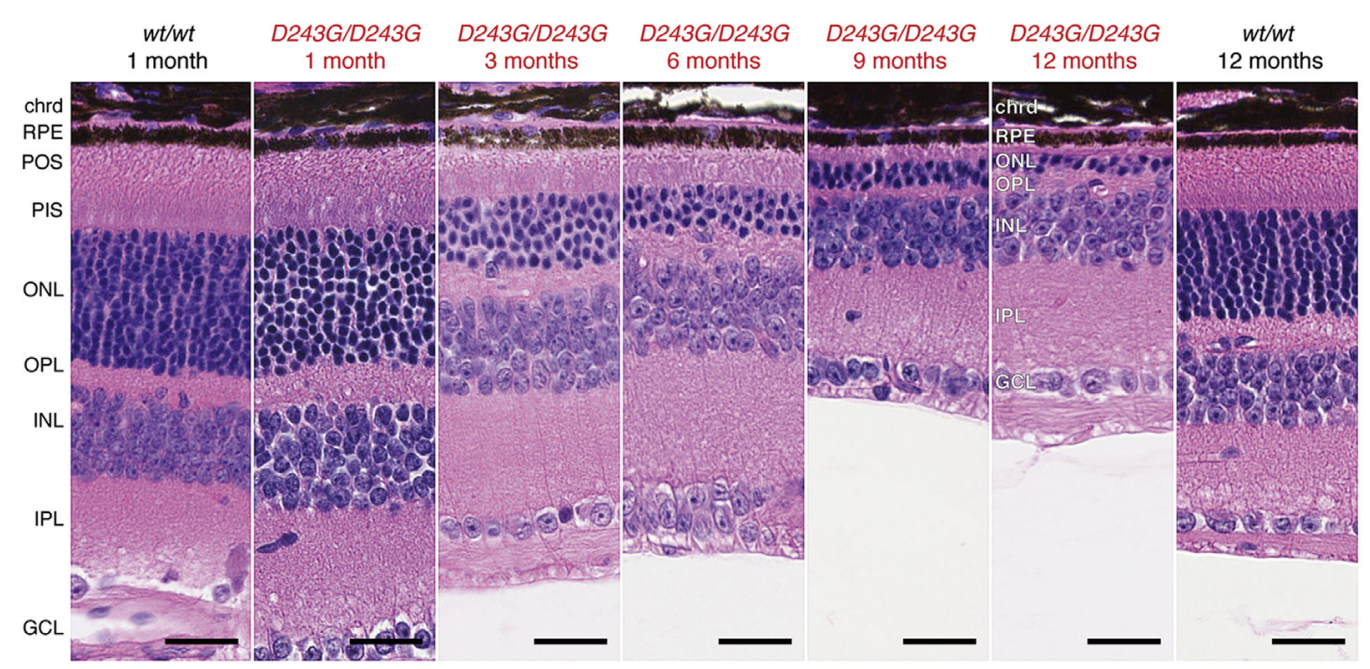

Figure 4 Light microscopy shows retinal degeneration. A: Nmnat ${ }^{V g M}$. Representative bright-field images of semithin $(1 \mu \mathrm{m})$ sections obtained from mice at the indicated ages stained with toluidine blue, which were acquired from the nasal retina at the plane of the optic nerve head. B: Nmnat $1^{D 243 G}$. Representative bright-field images of $5-\mu \mathrm{m}$ paraffin sections stained with hematoxylin and eosin. Rapid photoreceptor loss is observed in both mutant mouse lines. RPE degeneration is also evident in the V9M/V9M mice by 8 months of age (arrow). Scale bars: $50 \mu \mathrm{m}(\mathbf{A}) ; 25 \mu \mathrm{m}$ (B). Original magnification: $\times 30$ (A); $\times 40$ (B). chrd, choroid; D243G/D243G, homozygous Nmnat1 ${ }^{D 243 G}$; GCL, ganglion cell layer; INL, inner nuclear layer; IPL, inner plexiform layer; 0NL, outer nuclear layer; OPL, outer plexiform layer; PIS, photoreceptor inner segments; P0S, photoreceptor outer segments; RPE, retinal pigment epithelium; V9M/V9M, homozygous Nmnat1 ${ }^{\text {VgM }}$; wt/wt, wild-type.

and Nmnat ${ }^{D 243 G}$ mice show that the RPE cells also depend on NMNAT1 as they undergo degeneration, as do inner retinal cells (eg, bipolar cells) in the homozygous Nmnat $1^{V 9 M}$ mice. The development of pupillary amaurosis in homozygous Nmnat ${ }^{V 9 M}$ mice may indicate loss of intrinsically photosensitive ganglion cells in the advanced stage of the disease. ${ }^{5,6,55-57}$

Two hypotheses, which are not mutually exclusive, have been proposed to explain why mutations in NMNATI variants cause retinal disease. First, abnormal enzymatic activity in mutant NMNAT1 alters nuclear $\mathrm{NAD}^{+}$levels, and this loss of nuclear $\mathrm{NAD}^{+}$homeostasis interferes with important cellular processes. For example, DNA repair, gene transcription, and programed cell death are modulated by PARP1-mediated poly(ADP-ribosyl)ation, which is the main consumer of this $\mathrm{NAD}^{+}$pool. ${ }^{62-66}$ Similarly, nuclear sirtuins (eg, SIRT1, SIRT6, and SIRT7), which are important to cell survival because of their histone and transcription factor deacetylase activity, also rely on nuclear $\mathrm{NAD}^{+}{ }^{67,68}$ Failure of sirtuin function may be secondary to depletion of nuclear $\mathrm{NAD}^{+}$by activated PARP1. ${ }^{69}$ Evidence suggests that the degree to which NMNAT1 is catalytically dysfunctional depends on the mutation harbored, $8,10,27$ and such variability across mutants may explain individual differences in the rate of disease progression within the patient population. Second, NMNAT1 is hypothesized to act as a stress-response protein, and mutations could disrupt associated neuroprotective activity. This alternative role for NMNAT1 was observed in Drosophila where nmnat acts as a chaperone to facilitate neuronal 
A
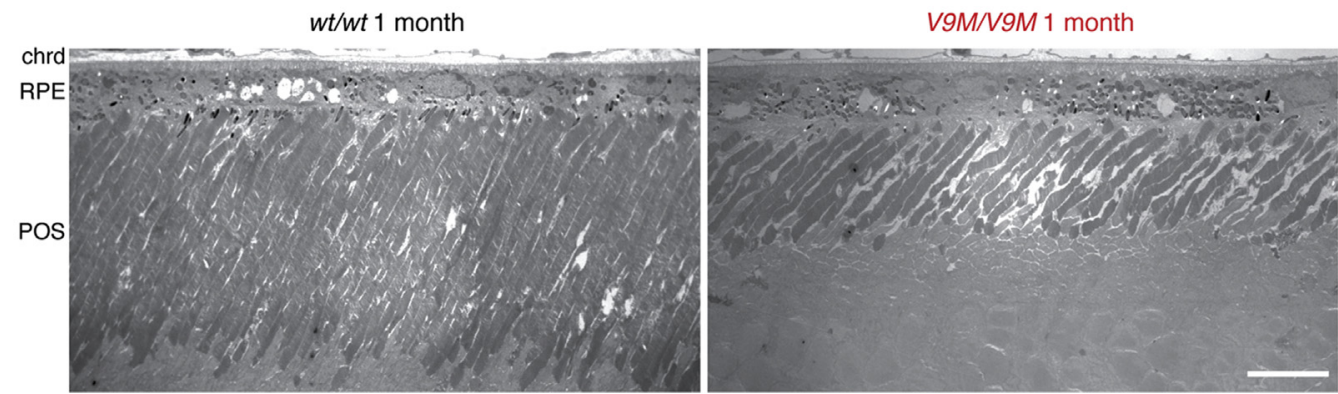

B
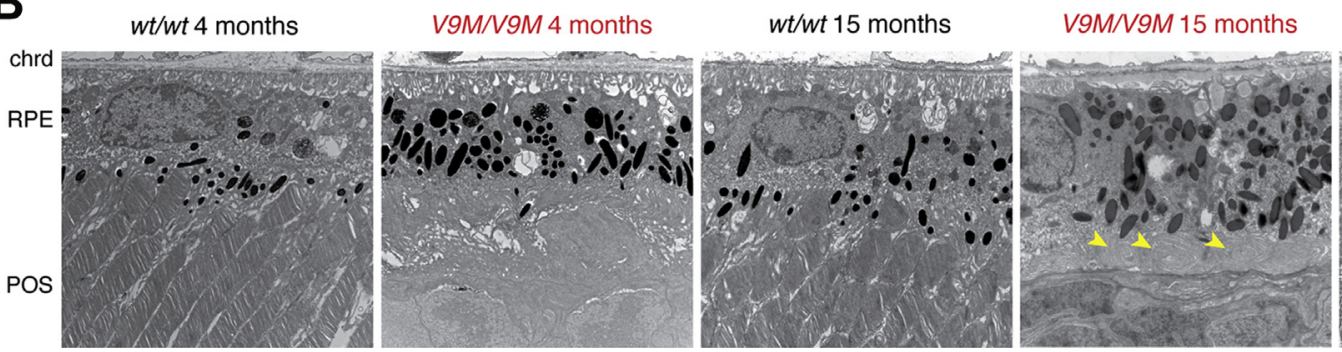

V9MN9M 15 months

Figure 5 Transmission electron microscopy shows morphologic changes in V9M/V9M photoreceptors and RPE. A: Representative images from 1-month-old mice show photoreceptor outer segments of normal length in the wt/wt retina compared with shortened outer segments in the V9M/V9M retina. B: Representative images acquired at the level of the RPE at 4 and 15 months in wt/wt and V9M/V9M retina, as indicated. Coiled apical processes are marked with arrowheads. Scale bars: $10 \mu \mathrm{m}$ (A); $3 \mu \mathrm{m}$ (B). Original magnification: $\times 1400$ (A); $\times 6800$ (B). chrd, choroid; P0S, photoreceptor outer segment; RPE, retinal pigment epithelium; V9M/V9M, homozygous Nmnat1 ${ }^{V 9 M}$; wt/wt, wild-type.

protection and neuronal maintenance when faced with axon injury or induced neurodegeneration in a manner independent of its $\mathrm{NAD}^{+}$synthase function. ${ }^{1,21,23}$ Similarly, the Wld ${ }^{\mathrm{S}}$ fusion protein, containing full-length Nmnat1 and a fragment of multiubiquitination factor Ube $4 b$, was found to delay neurodegeneration after nerve injury ${ }^{26}$ in mice, ${ }^{24}$ rats, ${ }^{25}$ and flies. ${ }^{21}$

The homozygous Nmnat ${ }^{V 9 M}$ and Nmnat1 $1^{D 243 G}$ mice are promising resources for understanding pathogenesis of retinal degeneration in NMNATI-associated LCA. These mouse models may help to distinguish whether and how altered NMNAT1 enzymatic and/or stress-response activity cause disease. The difference in the natural history of disease between these mouse strains, which are on the same genetic background (B6), should allow for correlative studies that answer questions about allelic variation and the disease progression. In addition, these mice may also be
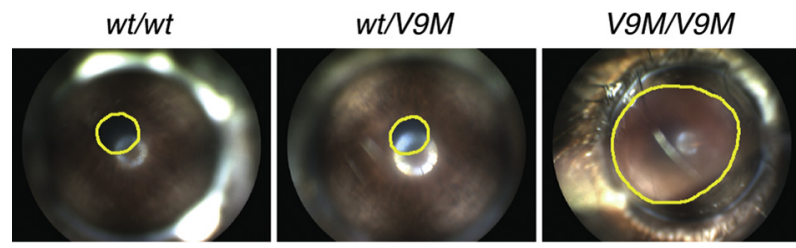

Figure 6 VIM/V9M mice develop amaurosis. Frames from video recordings of the eyes of 11.5-month-old $w t / w t$, wt/V9M, and V9M/V9M littermates on exposure to a steady light stimulus. Pupils are outlined in yellow. V9M/V9M, homozygous Nmnat1 ${ }^{\text {VMM }}$; wt/V9M, heterozygous Nmnat $1^{\text {VgM }} ; w t / w t$, wild-type. useful for defining the normal roles of NMNAT1 in the brain and other organs throughout the body.

The development of animal models that faithfully recapitulate NMNATI-associated LCA will facilitate the development of therapies for patients with this severe form of retinal degeneration. ${ }^{1,8-10}$ Gene augmentation therapy that uses adeno-associated virus vectors is especially attractive for treating inherited retinal degenerations on the basis of positive results from early clinical trials of adeno-associated virus-mediated gene therapy for RPE65-associated LCA, choroideremia, X-linked androleukodystrophy, and hemophilia, ${ }^{70-73}$ as well as the success of gene therapy in other animal models of inherited retinal degenerations. ${ }^{74-77}$ Studies are now in progress to test this approach using homozygous Nmnat1 ${ }^{V 9 M}$ mice. Given that amaurosis is observed in homozygous Nmnat ${ }^{V 9 M}$ mice, recovery of the pupillary light response could provide an additional noninvasive assessment of therapeutic efficacy ${ }^{78}$; this method was used in gene augmentation for RPE65-LCA in $\operatorname{dogs}^{79}$ and humans. ${ }^{72,80}$ Moreover, identifying the disease mechanisms underlying retinal degeneration in the homozygous Nmnat1 $^{\text {V9M }}$ and Nmnat1 ${ }^{\text {D243G }}$ mice may lead to more therapeutic options for patients with NMNATI-LCA.

\section{Acknowledgments}

We thank Carlos Aguilar, Joanne Dorning, Jeanie Hansen, and Philip Seifert for their technical assistance with the study and Scientific Services at The Jackson Laboratory, the 
Frozen Embryo and Sperm Archive (FESA) team at MRC Harwell, and the Mary Lyon Center at MRC Harwell.

\section{Supplemental Data}

Supplemental material for this article can be found at http://dx.doi.org/10.1016/j.ajpath.2016.03.013.

\section{References}

1. Perrault I, Hanein S, Zanlonghi X, Serre V, Nicouleau M, DefoortDelhemmes S, Delphin N, Fares-Taie L, Gerber S, Xerri O, Edelson C, Goldenberg A, Duncombe A, Le Meur G, Hamel C, Silva E, Nitschke P, Calvas P, Munnich A, Roche O, Dollfus H, Kaplan J, Rozet JM: Mutations in NMNAT1 cause Leber congenital amaurosis with early-onset severe macular and optic atrophy. Nat Genet 2012, 44:975-977

2. den Hollander AI, Roepman R, Koenekoop RK, Cremers FP: Leber congenital amaurosis: genes, proteins and disease mechanisms. Prog Retin Eye Res 2008, 27:391-419

3. Koenekoop RK: An overview of Leber congenital amaurosis: a model to understand human retinal development. Surv Ophthalmol 2004, 49: 379-398

4. den Hollander AI, Black A, Bennett J, Cremers FP: Lighting a candle in the dark: advances in genetics and gene therapy of recessive retinal dystrophies. J Clin Invest 2010, 120:3042-3053

5. Markwell EL, Feigl B, Zele AJ: Intrinsically photosensitive melanopsin retinal ganglion cell contributions to the pupillary light reflex and circadian rhythm. Clin Exp Optom 2010, 93:137-149

6. Gooley JJ, Ho Mien I, St Hilaire MA, Yeo SC, Chua EC, van Reen E, Hanley CJ, Hull JT, Czeisler CA, Lockley SW: Melanopsin and rodcone photoreceptors play different roles in mediating pupillary light responses during exposure to continuous light in humans. J Neurosci 2012, 32:14242-14253

7. Weleber RG, Francis PJ, Trzupek KM, Beattie C: Leber Congenital Amaurosis (GeneReviews). Seattle, WA: University of Washington, 2013

8. Falk MJ, Zhang Q, Nakamaru-Ogiso E, Kannabiran C, FonsecaKelly Z, Chakarova C, Audo I, Mackay DS, Zeitz C, Borman AD, Staniszewska M, Shukla R, Palavalli L, Mohand-Said S, Waseem NH, Jalali S, Perin JC, Place E, Ostrovsky J, Xiao R, Bhattacharya SS, Consugar M, Webster AR, Sahel JA, Moore AT, Berson EL, Liu Q, Gai X, Pierce EA: NMNAT1 mutations cause Leber congenital amaurosis. Nat Genet 2012, 44:1040-1045

9. Chiang PW, Wang J, Chen Y, Fu Q, Zhong J, Chen Y, Yi X, Wu R, Gan H, Shi Y, Chen Y, Barnett C, Wheaton D, Day M, Sutherland J, Heon E, Weleber RG, Gabriel LA, Cong P, Chuang K, Ye S, Sallum JM, Qi M: Exome sequencing identifies NMNAT1 mutations as a cause of Leber congenital amaurosis. Nat Genet 2012, 44: 972-974

10. Koenekoop RK, Wang H, Majewski J, Wang X, Lopez I, Ren H, Chen Y, Li Y, Fishman GA, Genead M, Schwartzentruber J, Solanki N, Traboulsi EI, Cheng J, Logan CV, McKibbin M, Hayward BE, Parry DA, Johnson CA, Nageeb M; Finding of Rare Disease Genes (FORGE) Canada Consortium, Poulter JA, Mohamed MD, Jafri H, Rashid Y, Taylor GR, Keser V, Mardon G, $\mathrm{Xu} \mathrm{H}$, Inglehearn $\mathrm{CF}, \mathrm{Fu} \mathrm{Q}$, Toomes $\mathrm{C}$, Chen R: Mutations in NMNAT1 cause Leber congenital amaurosis and identify a new disease pathway for retinal degeneration. Nat Genet 2012, 44: $1035-1039$

11. Deng Y, Huang H, Wang Y, Liu Z, Li N, Chen Y, Li X, Li M, Zhou X, Mu D, Zhong J, Wu J, Su Y, Yi X, Zhu J: A novel missense NMNAT1 mutation identified in a consanguineous family with Leber congenital amaurosis by targeted next generation sequencing. Gene 2015, 569:104-108

12. Jin $\mathrm{X}$, Qu LH, Meng XH, Xu HW, Yin ZQ: Detecting genetic variations in hereditary retinal dystrophies with next-generation sequencing technology. Mol Vis 2014, 20:553-560

13. Corton M, Nishiguchi KM, Avila-Fernandez A, Nikopoulos K, Riveiro-Alvarez R, Tatu SD, Ayuso C, Rivolta C: Exome sequencing of index patients with retinal dystrophies as a tool for molecular diagnosis. PLoS One 2013, 8:e65574

14. Siemiatkowska AM, van den Born LI, van Genderen MM, Bertelsen M, Zobor D, Rohrschneider K, van Huet RA, Nurohmah S, Klevering BJ, Kohl S, Faradz SM, Rosenberg T, den Hollander AI, Collin RW, Cremers FP: Novel compound heterozygous NMNAT1 variants associated with Leber congenital amaurosis. Mol Vis 2014, 20:753-759

15. Coppieters F, Van Schil K, Bauwens M, Verdin H, De Jaegher A, Syx D, Sante T, Lefever S, Abdelmoula NB, Depasse F, Casteels I, de Ravel T, Meire F, Leroy BP, De Baere E: Identity-by-descent-guided mutation analysis and exome sequencing in consanguineous families reveals unusual clinical and molecular findings in retinal dystrophy. Genet Med 2014, 16:671-680

16. Belenky P, Bogan KL, Brenner C: NAD + metabolism in health and disease. Trends Biochem Sci 2007, 32:12-19

17. Lau C, Niere M, Ziegler M: The NMN/NaMN adenylyltransferase (NMNAT) protein family. Front Biosci (Landmark Ed) 2009, 14 410-431

18. Chiarugi A, Dolle C, Felici R, Ziegler M: The NAD metabolome-a key determinant of cancer cell biology. Nat Rev Cancer 2012, 12: $741-752$

19. Berger F, Lau C, Dahlmann M, Ziegler M: Subcellular compartmentation and differential catalytic properties of the three human nicotinamide mononucleotide adenylyltransferase isoforms. J Biol Chem 2005, 280:36334-36341

20. Conforti L, Janeckova L, Wagner D, Mazzola F, Cialabrini L, Di Stefano M, Orsomando G, Magni G, Bendotti C, Smyth N, Coleman M: Reducing expression of NAD+ synthesizing enzyme NMNAT1 does not affect the rate of Wallerian degeneration. FEBS J 2011, 278:2666-2679

21. Zhai RG, Cao Y, Hiesinger PR, Zhou Y, Mehta SQ, Schulze KL, Verstreken P, Bellen HJ: Drosophila NMNAT maintains neural integrity independent of its NAD synthesis activity. PLoS Biol 2006, 4:e416

22. Zhai RG, Rizzi M, Garavaglia S: Nicotinamide/nicotinic acid mononucleotide adenylyltransferase, new insights into an ancient enzyme. Cell Mol Life Sci 2009, 66:2805-2818

23. Zhai RG, Zhang F, Hiesinger PR, Cao Y, Haueter CM, Bellen HJ NAD synthase NMNAT acts as a chaperone to protect against neurodegeneration. Nature 2008, 452:887-891

24. Mack TG, Reiner M, Beirowski B, Mi W, Emanuelli M, Wagner D, Thomson D, Gillingwater T, Court F, Conforti L, Fernando FS, Tarlton A, Andressen C, Addicks K, Magni G, Ribchester RR, Perry VH, Coleman MP: Wallerian degeneration of injured axons and synapses is delayed by a Ube $4 \mathrm{~b} / \mathrm{Nmnat}$ chimeric gene. Nat Neurosci 2001, 4:1199-1206

25. Adalbert R, Gillingwater TH, Haley JE, Bridge K, Beirowski B, Berek L, Wagner D, Grumme D, Thomson D, Celik A, Addicks K, Ribchester RR, Coleman MP: A rat model of slow Wallerian degeneration (WldS) with improved preservation of neuromuscular synapses. Eur J Neurosci 2005, 21:271-277

26. Gillingwater TH, Ribchester RR: Compartmental neurodegeneration and synaptic plasticity in the Wld(s) mutant mouse. J Physiol 2001, 534:627-639

27. Sasaki Y, Margolin Z, Borgo B, Havranek JJ, Milbrandt J: Characterization of Leber's congenital amaurosis-associated NMNAT1 mutants. J Biol Chem 2015, 290:17228-17238

28. Siemiatkowska AM, Schuurs-Hoeijmakers JH, Bosch DG, Boonstra FN, Riemslag FC, Ruiter M, de Vries BB, den 
Hollander AI, Collin RW, Cremers FP: Nonpenetrance of the most frequent autosomal recessive leber congenital amaurosis mutation in NMNAT1. JAMA Ophthalmol 2014, 132:1002-1004

29. Coghill EL, Hugill A, Parkinson N, Davison C, Glenister P, Clements S, Hunter J, Cox RD, Brown SD: A gene-driven approach to the identification of ENU mutants in the mouse. Nat Genet 2002, $30: 255-256$

30. Won J, Shi LY, Hicks W, Wang J, Naggert JK, Nishina PM: Translational vision research models program. Adv Exp Med Biol 2012, 723:391-397

31. Wansleeben C, van Gurp L, Feitsma H, Kroon C, Rieter E, Verberne M, Guryev V, Cuppen E, Meijlink F: An ENU-mutagenesis screen in the mouse: identification of novel developmental gene functions. PLoS One 2011, 6:e19357

32. Quwailid MM, Hugill A, Dear N, Vizor L, Wells S, Horner E, Fuller S, Weedon J, McMath H, Woodman P, Edwards D, Campbell D, Rodger S, Carey J, Roberts A, Glenister P, Lalanne Z, Parkinson N, Coghill EL, McKeone R, Cox S, Willan J, Greenfield A, Keays D, Brady S, Spurr N, Gray I, Hunter J, Brown SD, Cox RD: A gene-driven ENU-based approach to generating an allelic series in any gene. Mamm Genome 2004, 15:585-591

33. Thornton CE, Brown SD, Glenister PH: Large numbers of mice established by in vitro fertilization with cryopreserved spermatozoa: implications and applications for genetic resource banks, mutagenesis screens, and mouse backcrosses. Mamm Genome 1999, 10:987-992

34. Keays DA, Clark TG, Flint J: Estimating the number of coding mutations in genotypic- and phenotypic-driven N-ethyl-N-nitrosourea (ENU) screens. Mamm Genome 2006, 17:230-238

35. Buffone GJ, Darlington GJ: Isolation of DNA from biological specimens without extraction with phenol. Clin Chem 1985, 31:164-165

36. Blankenberg D, Von Kuster G, Coraor N, Ananda G, Lazarus R, Mangan M, Nekrutenko A, Taylor J: Galaxy: a web-based genome analysis tool for experimentalists. Curr Protoc Mol Biol 2010, Chapter 19. Unit 19.10.1-21

37. Giardine B, Riemer C, Hardison RC, Burhans R, Elnitski L, Shah P, Zhang Y, Blankenberg D, Albert I, Taylor J, Miller W, Kent WJ, Nekrutenko A: Galaxy: a platform for interactive large-scale genome analysis. Genome Res 2005, 15:1451-1455

38. Goecks J, Nekrutenko A, Taylor J; Galaxy Team: Galaxy: a comprehensive approach for supporting accessible, reproducible, and transparent computational research in the life sciences. Genome Biol 2010, 11:R86

39. Li H, Durbin R: Fast and accurate short read alignment with BurrowsWheeler transform. Bioinformatics 2009, 25:1754-1760

40. Li H, Handsaker B, Wysoker A, Fennell T, Ruan J, Homer N, Marth G, Abecasis G, Durbin R; 1000 Genome Project Data Processing Subgroup: The Sequence Alignment/Map format and SAMtools. Bioinformatics 2009, 25:2078-2079

41. Cingolani P, Platts A, Wang le L, Coon M, Nguyen T, Wang L, Land SJ, Lu X, Ruden DM: A program for annotating and predicting the effects of single nucleotide polymorphisms, SnpEff: SNPs in the genome of Drosophila melanogaster strain w1118; iso-2; iso-3. Fly (Austin) 2012, 6:80-92

42. Mattapallil MJ, Wawrousek EF, Chan CC, Zhao H, Roychoudhury J, Ferguson TA, Caspi RR: The Rd8 mutation of the Crb1 gene is present in vendor lines of C57BL/6N mice and embryonic stem cells, and confounds ocular induced mutant phenotypes. Invest Ophthalmol Vis Sci 2012, 53:2921-2927

43. Krishna VR, Alexander KR, Peachey NS: Temporal properties of the mouse cone electroretinogram. J Neurophysiol 2002, 87:42-48

44. Xu L, Ball SL, Alexander KR, Peachey NS: Pharmacological analysis of the rat cone electroretinogram. Vis Neurosci 2003, 20:297-306

45. Bush RA, Sieving PA: Inner retinal contributions to the primate photopic fast flicker electroretinogram. J Opt Soc Am A Opt Image Sci Vis 1996, 13:557-565

46. Kjellstrom S, Bush RA, Zeng Y, Takada Y, Sieving PA: Retinoschisin gene therapy and natural history in the Rs1h-KO mouse: long-term rescue from retinal degeneration. Invest Ophthalmol Vis Sci 2007, 48:3837-3845

47. Peachey NS, Goto Y, al-Ubaidi MR, Naash MI: Properties of the mouse cone-mediated electroretinogram during light adaptation. Neurosci Lett 1993, 162:9-11

48. Saszik SM, Robson JG, Frishman LJ: The scotopic threshold response of the dark-adapted electroretinogram of the mouse. J Physiol 2002, 543:899-916

49. Greenwald SH, Kuchenbecker JA, Roberson DK, Neitz M, Neitz J: Sopsin knockout mice with the endogenous M-opsin gene replaced by an L-opsin variant. Vis Neurosci 2014, 31:25-37

50. Lee Y, Kameya S, Cox GA, Hsu J, Hicks W, Maddatu TP, Smith RS, Naggert JK, Peachey NS, Nishina PM: Ocular abnormalities in Large(myd) and Large(vls) mice, spontaneous models for muscle, eye, and brain diseases. Mol Cell Neurosci 2005, 30:160-172

51. Schindelin J, Arganda-Carreras I, Frise E, Kaynig V, Longair M, Pietzsch T, Preibisch S, Rueden C, Saalfeld S, Schmid B, Tinevez JY, White DJ, Hartenstein V, Eliceiri K, Tomancak P, Cardona A: Fiji: an open-source platform for biological-image analysis. Nat Methods 2012, 9:676-682

52. Won J, Gifford E, Smith RS, Yi H, Ferreira PA, Hicks WL, Li T, Naggert JK, Nishina PM: RPGRIP1 is essential for normal rod photoreceptor outer segment elaboration and morphogenesis. Hum Mol Genet 2009, 18:4329-4339

53. Gresh J, Goletz PW, Crouch RK, Rohrer B: Structure-function analysis of rods and cones in juvenile, adult, and aged C57bl/6 and Balb/c mice. Vis Neurosci 2003, 20:211-220

54. Williams GA, Jacobs GH: Cone-based vision in the aging mouse. Vision Res 2007, 47:2037-2046

55. Lucas RJ, Douglas RH, Foster RG: Characterization of an ocular photopigment capable of driving pupillary constriction in mice. Nat Neurosci 2001, 4:621-626

56. Lucas RJ, Hattar S, Takao M, Berson DM, Foster RG, Yau KW: Diminished pupillary light reflex at high irradiances in melanopsinknockout mice. Science 2003, 299:245-247

57. Zhu Y, Tu DC, Denner D, Shane T, Fitzgerald CM, Van Gelder RN: Melanopsin-dependent persistence and photopotentiation of murine pupillary light responses. Invest Ophthalmol Vis Sci 2007, 48:1268-1275

58. Ames A 3rd: Energy requirements of CNS cells as related to their function and to their vulnerability to ischemia: a commentary based on studies on retina. Can J Physiol Pharmacol 1992, 70 Suppl: S158-S164

59. Ames A 3rd, Li YY, Heher EC, Kimble CR: Energy metabolism of rabbit retina as related to function: high cost of $\mathrm{Na}+$ transport. $\mathrm{J}$ Neurosci 1992, 12:840-853

60. Niven JE, Laughlin SB: Energy limitation as a selective pressure on the evolution of sensory systems. J Exp Biol 2008, 211:1792-1804

61. Wong-Riley MT: Energy metabolism of the visual system. Eye Brain 2010, 2:99-116

62. Berger F, Lau C, Ziegler M: Regulation of poly(ADP-ribose) polymerase 1 activity by the phosphorylation state of the nuclear NAD biosynthetic enzyme NMN adenylyl transferase 1. Proc Natl Acad Sci U S A 2007, 104:3765-3770

63. Bouchard VJ, Rouleau M, Poirier GG: PARP-1, a determinant of cell survival in response to DNA damage. Exp Hematol 2003, 31: 446-454

64. Yu SW, Andrabi SA, Wang H, Kim NS, Poirier GG, Dawson TM, Dawson VL: Apoptosis-inducing factor mediates poly(ADP-ribose) (PAR) polymer-induced cell death. Proc Natl Acad Sci U S A 2006, 103:18314-18319

65. Yu SW, Wang H, Poitras MF, Coombs C, Bowers WJ, Federoff HJ, Poirier GG, Dawson TM, Dawson VL: Mediation of poly(ADPribose) polymerase-1-dependent cell death by apoptosis-inducing factor. Science 2002, 297:259-263

66. Kim MY, Zhang T, Kraus WL: Poly(ADP-ribosyl)ation by PARP-1: 'PAR-laying' NAD+ into a nuclear signal. Genes Dev 2005, 19 : 1951-1967 
67. Houtkooper RH, Pirinen E, Auwerx J: Sirtuins as regulators of metabolism and healthspan. Nat Rev Mol Cell Biol 2012, 13: 225-238

68. Chalkiadaki A, Guarente L: Sirtuins mediate mammalian metabolic responses to nutrient availability. Nat Rev Endocrinol 2012, 8: $287-296$

69. Canto C, Auwerx J: Interference between PARPs and SIRT1: a novel approach to healthy ageing? Aging (Albany NY) 2011, 3:543-547

70. Nathwani AC, Tuddenham EG, Rangarajan S, Rosales C, McIntosh J, Linch DC, Chowdary P, Riddell A, Pie AJ, Harrington C, O'Beirne J, Smith K, Pasi J, Glader B, Rustagi P, Ng CY, Kay MA, Zhou J, Spence Y, Morton CL, Allay J, Coleman J, Sleep S, Cunningham JM, Srivastava D, Basner-Tschakarjan E, Mingozzi F, High KA, Gray JT, Reiss UM, Nienhuis AW, Davidoff AM: Adenovirus-associated virus vector-mediated gene transfer in hemophilia B. N Engl J Med 2011, 365:2357-2365

71. Maguire AM, Simonelli F, Pierce EA, Pugh EN Jr, Mingozzi F, Bennicelli J, Banfi S, Marshall KA, Testa F, Surace EM, Rossi S, Lyubarsky A, Arruda VR, Konkle B, Stone E, Sun J, Jacobs J, Dell'Osso L, Hertle R, Ma JX, Redmond TM, Zhu X, Hauck B, Zelenaia O, Shindler KS, Maguire MG, Wright JF, Volpe NJ, McDonnell JW, Auricchio A, High KA, Bennett J: Safety and efficacy of gene transfer for Leber's congenital amaurosis. N Engl J Med 2008, 358:2240-2248

72. Cideciyan AV, Aleman TS, Boye SL, Schwartz SB, Kaushal S, Roman AJ, Pang JJ, Sumaroka A, Windsor EA, Wilson JM, Flotte TR, Fishman GA, Heon E, Stone EM, Byrne BJ, Jacobson SG, Hauswirth WW: Human gene therapy for RPE65 isomerase deficiency activates the retinoid cycle of vision but with slow rod kinetics. Proc Natl Acad Sci U S A 2008, 105:15112-15117

73. Cartier N, Hacein-Bey-Abina S, Bartholomae CC, Veres G, Schmidt M, Kutschera I, Vidaud M, Abel U, Dal-Cortivo L, Caccavelli L, Mahlaoui N, Kiermer V, Mittelstaedt D, Bellesme C, Lahlou N, Lefrere F, Blanche S, Audit M, Payen E, Leboulch P, l'Homme B, Bougneres P, Von Kalle C, Fischer A, CavazzanaCalvo M, Aubourg P: Hematopoietic stem cell gene therapy with a lentiviral vector in X-linked adrenoleukodystrophy. Science 2009, 326:818-823

74. Min SH, Molday LL, Seeliger MW, Dinculescu A, Timmers AM, Janssen A, Tonagel F, Tanimoto N, Weber BH, Molday RS, Hauswirth WW: Prolonged recovery of retinal structure/function after gene therapy in an Rs1h-deficient mouse model of $\mathrm{x}$-linked juvenile retinoschisis. Mol Ther 2005, 12:644-651

75. Pang JJ, Boye SL, Kumar A, Dinculescu A, Deng W, Li J, Li Q, Rani A, Foster TC, Chang B, Hawes NL, Boatright JH, Hauswirth WW: AAV-mediated gene therapy for retinal degeneration in the rd10 mouse containing a recessive PDEbeta mutation. Invest Ophthalmol Vis Sci 2008, 49:4278-4283

76. Alexander JJ, Umino Y, Everhart D, Chang B, Min SH, Li Q, Timmers AM, Hawes NL, Pang JJ, Barlow RB, Hauswirth WW: Restoration of cone vision in a mouse model of achromatopsia. Nat Med 2007, 13:685-687

77. Tam LC, Kiang AS, Kennan A, Kenna PF, Chadderton N, Ader M, Palfi A, Aherne A, Ayuso C, Campbell M, Reynolds A, McKee A, Humphries MM, Farrar GJ, Humphries P: Therapeutic benefit derived from RNAi-mediated ablation of IMPDH1 transcripts in a murine model of autosomal dominant retinitis pigmentosa (RP10). Hum Mol Genet 2008, 17:2084-2100

78. Park JC, Moura AL, Raza AS, Rhee DW, Kardon RH, Hood DC: Toward a clinical protocol for assessing rod, cone, and melanopsin contributions to the human pupil response. Invest Ophthalmol Vis Sci 2011, 52:6624-6635

79. Acland GM, Aguirre GD, Ray J, Zhang Q, Aleman TS, Cideciyan AV, Pearce-Kelling SE, Anand V, Zeng Y, Maguire AM, Jacobson SG, Hauswirth WW, Bennett J: Gene therapy restores vision in a canine model of childhood blindness. Nat Genet 2001, 28 : 92-95

80. Aguirre GK, Komaromy AM, Cideciyan AV, Brainard DH, Aleman TS, Roman AJ, Avants BB, Gee JC, Korczykowski M, Hauswirth WW, Acland GM, Aguirre GD, Jacobson SG: Canine and human visual cortex intact and responsive despite early retinal blindness from RPE65 mutation. PLoS Med 2007, 4:e230 